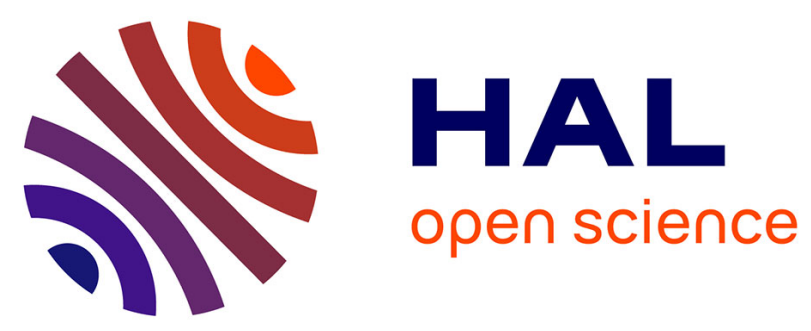

\title{
Role of inherited structure on granite emplacement: An example from the Late Jurassic Shibei pluton in the Wuyishan area (South China) and its tectonic implications
}

\author{
Hongsheng Liu, Yan Chen, Bo Wang, Michel Faure, Saskia Erdmann, \\ Guillaume Martelet, Bruno Scaillet, Fangfang Huang
}

\section{To cite this version:}

Hongsheng Liu, Yan Chen, Bo Wang, Michel Faure, Saskia Erdmann, et al.. Role of inherited structure on granite emplacement: An example from the Late Jurassic Shibei pluton in the Wuyishan area (South China) and its tectonic implications. Tectonophysics, 2020, 779, pp.228394. 10.1016/j.tecto.2020.228394 . insu-02496416

\section{HAL Id: insu-02496416 https://hal-insu.archives-ouvertes.fr/insu-02496416}

Submitted on 3 Mar 2020

HAL is a multi-disciplinary open access archive for the deposit and dissemination of scientific research documents, whether they are published or not. The documents may come from teaching and research institutions in France or abroad, or from public or private research centers.
L'archive ouverte pluridisciplinaire HAL, est destinée au dépôt et à la diffusion de documents scientifiques de niveau recherche, publiés ou non, émanant des établissements d'enseignement et de recherche français ou étrangers, des laboratoires publics ou privés. 


\section{Journal Pre-proof}

Role of inherited structure on granite emplacement: An example from the Late Jurassic Shibei pluton in the Wuyishan area (South China) and its tectonic implications

Hongsheng Liu, Yan Chen, Bo Wang, Michel Faure, Saskia Erdmann, Guillaume Martelet, Bruno Scaillet, Fangfang Huang

TEGTONOPHYSICS

mater

PII: $\quad$ S0040-1951(20)30077-9

DOI: $\quad$ https://doi.org/10.1016/j.tecto.2020.228394

Reference: $\quad$ TECTO 228394

To appear in: $\quad$ Tectonophysics

Received date: $\quad 14$ May 2019

Revised date: $\quad 24$ February 2020

Accepted date: $\quad 29$ February 2020

Please cite this article as: H. Liu, Y. Chen, B. Wang, et al., Role of inherited structure on granite emplacement: An example from the Late Jurassic Shibei pluton in the Wuyishan area (South China) and its tectonic implications, Tectonophysics(2020), https://doi.org/ 10.1016/j.tecto.2020.228394

This is a PDF file of an article that has undergone enhancements after acceptance, such as the addition of a cover page and metadata, and formatting for readability, but it is not yet the definitive version of record. This version will undergo additional copyediting, typesetting and review before it is published in its final form, but we are providing this version to give early visibility of the article. Please note that, during the production process, errors may be discovered which could affect the content, and all legal disclaimers that apply to the journal pertain.

(C) 2020 Published by Elsevier. 


\title{
Role of inherited structure on granite emplacement: An example from the Late Jurassic Shibei pluton in the Wuyishan area (South China) and its tectonic implications
}

\author{
Hongsheng Liu ${ }^{1,2,3}$, Yan Chen ${ }^{2}$, Bo Wang ${ }^{1, ~}$, Michel Faure ${ }^{2}$, Saskia Erdmann ${ }^{2}$, Guillaume \\ Martelet $^{4}$, Bruno Scaillet ${ }^{2}$, Fangfang Huang ${ }^{1,2}$ \\ ${ }^{1}$ State Key Laboratory for Mineral Deposits Research, School of Earth Sciences and \\ Engineering, Nanjing University, 210023 Nanjing, China. \\ ${ }^{2}$ Univ. Orléans, CNRS, BRGM, ISTO, UMR 7327, F-45071, Orléans, France. \\ ${ }^{3}$ School of Geoscience and Info Physics, Central South University, Changsha 410083, China. \\ ${ }^{4}$ BRGM, UMR 7327, BP 36009, 45060, Orléans, France. \\ ${ }^{*}$ Corresponding author: Bo Wang (bwang@nju.edu.cn)
}

\section{Abstract}

The Shibei pluton is a Late Jurassic granitic body in the South China Block (Fujian province), featured by macroscopically isotropic granite and undeformed margins, which are also characteristics for most of the Late Jurassic plutons in southeastern China. Our field observations, fabric investigations and gravity modeling allow us to decipher the internal structure, overall geometry, magma accumulation and emplacement processes of the Shibei pluton. Magnetic fabrics of the Shibei pluton can be divided into two distinct groups. The first one, observed in the southern-central part of the pluton, is characterized by high-angle to sub-vertical $\left(54^{\circ}-90^{\circ}\right) \mathrm{NE}-\mathrm{SW}$-striking magnetic foliations and variably plunging magnetic lineation. The second group, recognized in the northern part of the pluton, shows variably dipping $\left(22^{\circ}-88^{\circ}\right)$ magnetic foliation, which generally strikes subparallel to pluton-country 
rock contacts, and irregularly oriented magnetic lineation. The Bouguer gravity modeling demonstrates that the pluton has a tabular geometry with a N-S-striking long axis, and a length-width-thickness ratio of $\sim 32: 8: 1$. The intrusion thickness gradually decreases from the southwest margin (ca. $2.5 \mathrm{~km}$ ) to the northeast margin (ca. $0.5 \mathrm{~km})$. Moreover, an undulating bottom with one or more convex intruding roots can be observed. Integrating published geochronological and regional tectonic data, we propose that the Shibei pluton was constructed by successive NE-SW-striking magma injections. Emplacement of early magma batches started in the SW part of the pluton by magma injection, which was guided by inherited structures produced by pre-emplacement tectonic events. Continuous magma injections were laterally accreted to earlier emplaced magma intrusions, and/or injected along lithological and/or structural discontinuities within the country rocks at upper crustal level without producing ductile deformation in the pluton-country rock contact zone. Our structural and fabric investigations indicate that the SE South China Block was not subjected to a major tectonic deformation during the Late Jurassic period.

Keywords: Magma emplacement, AMS, gravity modelling, structural inheritance, Shibei Pluton, South China Block. 


\section{Introduction}

Understanding how magma is emplaced (such as by sills, dykes or diapirs) is crucial for characterizing pluton construction processes and for deciphering the interplay between magmatism and crustal structures and thus regional tectonic context (e.g., Pitcher, 1979; Iyer, 1984; Parterson et al., 1989; Borradaile and Kehlenbeck, 1996; Ferré et al., 1997; Maes et al., 2007; Žák et al., 2017). Through detailed studies on plutons and their country rocks, including petrology, petro-fabrics, geochronology, geometry and numerical modelling studies, several emplacement hypotheses were proposed, e.g., diapirism (Roberts, 1970; Dixon, 1975; Cruden, 1990; Paterson and Vernon, 1995; Polyansky et al., 2010), ballooning (Bateman, 1984; Brown and McClelland, 2000; Schoene et al., 2012), dyke and sill models (Rubin, 1993; Weinberg, 1999; Burchardt, 2008; Mathieu et al., 2008; Gudmundsson, 2011; Schofield et al., 2012), laccolith and lopolith (Corry, 1988; Scaillet et al., 1995; Morgan and McGovern, 2005; de Saint-Blanquat et al., 2006; Roman et al., 2016), stoping (Daly, 1903; Glazner, 2006, 2007; Paterson, 2008; Huber et al., 2011) and syn-tectonic emplacement (Pitcher, 1979; Hutton, 1988; Tikoff et al., 1999; Allibon et al., 2011; de Saint-Blanquat et al., 2011; Wei et al., 2014). These hypotheses can be briefly classified into two major models in terms of the space-creating mechanism for magma emplacement, i.e. forceful and permissive, in which magmas either forcefully make space for a pluton or permissively intrude into their country rocks under regional tectonics (Pitcher, 1979; Hutton, 1988; Daly, 1903). Nevertheless, both models only emphasized the role of magma and/or regional tectonics in space creation during emplacement, and paradoxes exist in these models when they are applied to regions with intensive magmatism but a very weak tectonic record. For example, in the South China Block 
(SCB in Fig. 1a) where Jurassic magmatic intrusions and relatively weak regional tectonics occurred (Liu et al., 2018). Many studies have revealed that crustal rheology related to variable chemical composition, crustal layering, thermal gradients, fracture condition of the crust, and especially inherited and/or active structures can facilitate magma ascent and emplacement (Gudmundsson, 2011; Menand, 2011 and references therein; Blundy and Annen, 2016; Liu et al., 2018). Therefore, other than regional tectonics and magma itself, additional factors should be considered in the study of "space-creation" during magma emplacement, and that will in turn reflect the regional tectonics.

Granitic rocks, especially peraluminous to metaluminous granites, are the products of crustal partial melting, usually with involvement of supracrustal rocks, which were melted in the lower to middle crust, while magma emplacement occurred in the middle to upper crust (Douce et al., 1990; Sylvester and Liegeois, 1998; Annen et al., 2006). The rocks in the upper crust are often brittlely deformed to develop fractures, faults and folds during multi-staged tectonic events. How upper crustal structures inherited from previous tectonic events influence transport and emplacement of granitic magma is not well understood. Thus, the study of the assembly of granitic plutons is critical to assess the role of inherited crustal structures on magma ascent and emplacement.

Voluminous metaluminous to peraluminous granites are exposed in the southeast of the South China Block (Fig. 1a and 1b), which is also referred to as the Old Land of Cathaysia (Grabau, 1924), the Cathaysia Block (Li and Kinny, 2002), or the South China Fold Belt (Huang, 1945). The granites range in ages from 250 to 60 Ma (Fig. 1b; Zhou et al., 2006), and cover a large zone that is $\sim 1500 \mathrm{~km}$ long and $800 \mathrm{~km}$ wide. Although the nature, 
formation, and distribution of the Precambrian basement of the Cathaysia Block are still disputed (Yu et al., 2009; Charvet et al., 2010; Li et al., 2010; Ren and Li, 2016; Chen et al., 2018), it is generally accepted that the block was assembled by several sub-units with distinct crystalline basement (Li, 1997; Xiang et al., 2008; Yu et al., 2009; Li et al., 2011; Xia et al., 2012; Zhao et al., 2018). Polyphase pre-Mesozoic tectonic and thermal events are recorded in this block, indicating that it was intensively deformed and reworked (Zhao and Cawood, 1999; Liu et al., 2010; Li et al., 2017 and references therein). The Middle to Late Jurassic granitic plutons were intruded in the highly deformed upper crustal rocks of the Cathaysia Block, and are therefore suitable candidates for the study of magma emplacement in a deformed region, and evaluation of the role of inherited structures in magma emplacement. Furthermore, previous studies have suggested that the fabric developed inside a pluton can reflect the regional tectonic regime (e.g., Hutton, 1988; Paterson et al., 1989; Ferré and Améglio, 2000; Allibon et al., 2011). This will help delineate the hotly disputed tectonic settings of the Late Jurassic magmatism, which were variably described as related to lithosphere extension (Li et al., 2003; Wang et al., 2003), a mantle plume (Xie et al., 1996), the subduction of the paleo-Pacific Plate (Guo et al., 1980; Zhou and Li, 2000), and delamination of the lower continental crust (Wang et al., 2004, 2005).

The Late Jurassic Shibei pluton, intruded into the intensively deformed Neoproterozoic Mayuan Group in the Wuyishan area (Figs. 1b and 2a; Zhao and Cawood, 1999; Chen et al., 2018), is one of the representative Mesozoic granitic bodies in the southeast of the SCB (Fig. 1b), in terms of emplacement age, lithology, texture and structure, pluton size and intrusion depth. It is therefore chosen in this study as the target to investigate magma emplacement 
mechanism. The following approaches were applied to the Shibei pluton to decipher its formation: (1) detailed field observations and statistical structure analysis were performed on both the Shibei pluton and its country rocks to delineate the relationships between the regional structures and the intrusion-induced ones; (2) thin section observations and anisotropy of magnetic susceptibility (AMS) investigations were conducted to characterize mineral assemblages and micro-textures of the macroscopically isotropic and homogenous granite; (3) the pluton emplacement depth was estimated using Qtz- and (Ab+Or)-geobarometers; and (4) gravity modelling was applied to determine the 3D geometry of the pluton. Combining these new results and the previous data, an emplacement model is proposed for the Shibei pluton.

\section{Geological background}

\subsection{Geological setting of the Cathaysia Block}

The Cathaysia Block is one of the two constituent Precambrian blocks of the South China Block that was formed by a Neoproterozoic collision between the Cathaysia Block in the southeast and the Yangtze Craton in the northwest along the NE-SW-trending Jiangnan orogenic belt (Fig. 1a and 1b) (Guo et al., 1989; Wang and Mo, 1995; Shu and Charvet, 1996; Li et al., 2008; Zhang et al., 2013; Yao et al., 2016). Geochronological, geochemical and geophysical studies indicate that the Cathaysia Block is likely composed of several sub-units represented by Paleoproterozoic to Neoproterozoic metamorphic and crystalline (granitic) basement rocks recognized in the Wuyishan, Nanling, and Yunkaidashan domains (light brown shadow areas in Fig. 1b; Zhang et al., 1984; Guo et al., 1989; Gilder et al., 1995; Yu et al., 2009, 2010). These different domains show distinct age spectra of detrital zircons and initial Sr-Nd isotopic ratios of pre-Paleozoic rocks (Chen and Jahn, 1998; Yu et al., 2010; Yao 
et al., 2011; Xia et al., 2012 and references therein), as well as variable density layers (Deng et al., 2014). The nature and location of tectonic boundaries between the sub-units remain unclear.

After the Neoproterozoic amalgamation of the Cathaysia and Yangtze blocks, Late Neoproterozoic rifting generated the Nanhua rift associated with intraplate magmatism that is documented in the Cathaysia Block (Wang and Li, 2003; Li et al., 2008; Shu et al., 2011; Zhao et al., 2018 and references therein). Early Paleozoic tectonics are characterized by an intracontinental orogeny, which deformed the Late Neoproterozoic to Ordovician terrigenous rocks and carbonate by producing S-verging and NW-verging thrust in different parts of the Cathaysia Block associated with locally developed sinistral shearing at $\sim 450-400 \mathrm{Ma}$ (Lin et al., 2008; Faure et al., 2009; Charvet et al., 2010; Li et al., 2010, 2017; Shu et al., 2014). The Precambrian basement of the Cathaysia Block was also reworked under amphibolite facies metamorphic conditions, as represented by widespread migmatites and S-type granites dated at $450-420 \mathrm{Ma}$ in the Wuyi and Yunkaidashan domains (Lin et al., 2008; Li et al., 2010; Liu et al., 2010; Wang et al., 2010, 2013a, 2013b, 2014; Xu et al., 2011, 2015; Shu et al., 2015; Chen et al., 2018).

Mesozoic tectonic and thermal events affected most parts of the Cathaysia Block and produced the Late Triassic intracontinental Xuefengshan Belt along the NW margin of the Cathaysia Block (Chu et al., 2012a, 2012b, 2018), and locally developed dextral shear zones inside of the Cathaysia Block (Zhang and Cai, 2009; Xu et al., 2011; Li et al., 2017). All pre-Triassic rocks were involved in the Middle Triassic orogeny. In contrast, the NE-SW-striking Late Jurassic to Early Cretaceous strata in the study area are mainly 
composed of sandstone, siltstone and volcanoclastic rocks, and lack evidence for ductile deformation with only gentle tilting of the strata (Fig. 2a; BGMRFP, 1985), which unconformably overlie the Neoproterozoic to Paleozoic strata. Moreover, Triassic peraluminous granitic magmatism also affected the study area, which is interpreted as the product of partial melting of continental crust (Wang et al., 2012 and references therein; Zhu et al., 2013, 2016).

Accordingly, the Cathaysia Block was intensively deformed by a succession of pre-Jurassic tectonic events that formed the composite South China Fold Belt (Fig. 1b; Huang, 1945). Voluminous Mesozoic plutons ranging in age from Late Triassic to Cretaceous intruded in the Proterozoic to Late Mesozoic rocks (Zhou et al., 2006).

\subsection{The Shibei pluton and its country rocks}

The Shibei pluton, located in the Wuyishan area, NE of the Cathaysia Block (Figs. 1b and $2 \mathrm{a}$ ), is an intrusive complex with an exposed surface of $\sim 570 \mathrm{~km}^{2}$ and a topographic relief of 500 meters (Table 1). The Shibei pluton exposure shows a N-S-elongated geometry with a surface length/width ratio of $\sim 6: 1$ (Fig. 2a). It is mainly composed of Late Jurassic granites ( 155 Ma; Wang et al., 2016). The dominant lithologies of the pluton include medium- to coarse-grained biotite granite, locally developed monzogranite and porphyritic K-feldspar granite with feldspar phenocrysts ranging from 1 to $5 \mathrm{~cm}$ in size (Fig. 3a, 3b, and 3c). No lithological zonation or intrusive contact can be identified from the current exposure, although the locally developed small-scale porphyritic K-feldspar granitic/rhyolitic intrusions are much younger ( 110 Ma, Fig. 2a; Wang et al., 2016). 
The Shibei granites show typical isotropic and homogeneous textures in the field. Randomly oriented mafic enclaves with sizes ranging from 5 to $20 \mathrm{~cm}$ and length/width ratios between 1 and 1.3 are locally found in the Shibei pluton. A previous geochemical study shows that the Shibei granites have moderately high alumina saturation index (ASI $=1.0$ to 1.1$)$ and negative zircon $\varepsilon \mathrm{Hf}$ and whole-rock $\varepsilon \mathrm{Nd}$ values (-15.7 and -14.5 , respectively), indicating partial melting of continental crust with a high degree of fractionation (Wang et al., 2016).

The Shibei pluton intruded in the Neoproterozoic Mayuan Group, which is mainly composed of phyllites, micaschists, gneisses, and migmatites. These country rocks were subject to polyphase deformation during several successive regional tectonic events prior to the Jurassic magmatism, resulting in the current NE-SW-striking fold-and-fault system (Zhao and Cawood, 1999; Chen et al., 2018). These structures were re-shaped or enforced by NE-SW-striking Cretaceous extensional tectonics (Ren et al., 2002; Li et al., 2014). However, the Shibei pluton is located in a tropical climatic zone, the granites and country rocks are strongly weathered and covered by vegetation, and available outcrops are limited. Nevertheless, the limited field structural data show a good consistency in strike and are also consistent with the regional structures according to the geological map (Fig. 2a; BGMRFP, 1985). Thus, we believe that these data represent the general structural pattern of the country rocks in the study area.

According to our field survey, intrafolial folds and "S-shaped" leucosomes in the migmatite (Fig. 3d), quartz-boudinage in the schist (Fig. 3e), and crenulation of phyllites (Fig. 3f) are widely developed in country rocks of the Shibei pluton. In addition, the contact 
between the pluton and country rocks is sharp and geometrically concordant with the country rock foliation (Fig. 3g). Biotite schlieren were observed close to the pluton's northwestern margin (Fig. 3b, site S03 in Fig. 7a), being subparallel to the pluton-country rock contact. A slight bulging of the country rocks along the contact was also observed implying the deflection of the country rock during magma emplacement. Mineral preferred orientation along the pluton's margins is rarely observed in the field and no obvious thermal aureole can be recognized in the country rocks; however, contamination of the granite by the country rocks can be locally observed (Fig. 3g). Post-solidus relative movement along the contact was not observed.

\section{Fabric investigation of the Shibei pluton}

To reveal mineral assemblages, petrographic textures and microtectonic features of the macroscopically homogeneous and isotropic Shibei granites, several tens of massive, fresh, and oriented samples were collected for thin section observation and a total of 230 core specimen for magnetic fabric measurement were sampled from 37 fresh outcrops $(>20 \mathrm{~m}$ wide) evenly distributed within the pluton (Fig. 2). The AMS cores were drilled out by a portable gasoline drill with core lengths of $\sim 4-7 \mathrm{~cm}$. The core samples were oriented by magnetic compass, and when the weather allowed the solar compass was also used to avoid the influence of any potential local magnetic anomaly. An average azimuth difference value of $-7^{\circ}$ was calculated between the magnetic and solar azimuths, which were used for the azimuth correction for samples without solar measurements. In the laboratory, specimen of $2.2 \mathrm{~cm}$ long and $2.5 \mathrm{~cm}$ in diameter were prepared from the collected cores. 


\subsection{Thin section observations}

The oriented massive granite samples and some core specimens were prepared for thin section investigation. The macroscopically isotropic massive samples were cut along the vertical plane as the majority of the magnetic foliations are vertical to sub-vertical. In addition, the core specimen samples were cut perpendicular to the magnetic foliation and parallel to the magnetic lineation. Under the microscope, the Shibei granites are mainly composed of quartz, plagioclase and/or K-feldspar, biotite, sericite, magnetite and/or pyrite, and accessory minerals such as zircon, sphene, and apatite, with locally developed amphibole (Fig. 4). They generally have a typical magmatic texture (Sample S05, S10, S19, S21 and S27; Fig. 4) showing euhedral crystals, well-preserved twinning and oscillatory zoning of the plagioclase and K-feldspars and straight grain boundaries. Undulose extinction of quartz is locally observed in the granite sampled near the pluton margin (Fig. 4e). Some samples from the central part of the pluton (sample S19; Fig. 4b), display a clear magmatic texture, but they show local bulging recrystallization of quartz grains, indicating weak sub-solidus deformation. However, no consistent sub-solidus deformation can be recognized in two neighboring sites, indicating that this weak sub-solidus deformation is not due to a regional tectonic event but may have been the result of interaction between early emplaced intrusions and later injections or interaction with the pluton roof during emplacement. Magnetite is common in most samples, occurring as irregularly shaped inclusions in feldspar and biotite or as interstitial crystals (Figs. 4f).

\subsection{Magnetic fabric measurements}

The nature of magnetic minerals is critical for the interpretation of AMS results 
(Rochette et al., 1992). Three methods were applied to core specimen in order to reveal types and compositions of magnetic minerals, including (1) thermomagnetic mineral analysis using a KLY3 kappabridge coupled with a CS3 furnace, (2) Isothermal Remanence Magnetization (IRM) measurements with an IM30 pulsed magnetizer and a JR5 spinner magnetometer, and (3) magnetic hysteresis loop curve acquisition using a vibrating magnetometer. The first and second experiments were conducted in the Laboratoire de Magnétisme des Roches d'Orléans at the Institut des Sciences de la Terre d'Orléans (ISTO, France), and the third method was carried out at the Laboratoire de Paleomagnétisme of the Institut de Physique du Globe de Paris (IPGP). Then AMS measurements were performed at ISTO with the KLY-3 kapabridge, and the statistical results were obtained using the open resource software Anisoft 4.2 of AGICO (www.agico.com).

\subsubsection{Magnetic mineral analysis}

The thermal magnetic mineralogical measurements (Fig. 5a-5c) show a gradual drop in magnetic susceptibility at $350-400{ }^{\circ} \mathrm{C}$ and a rapid drop at $580{ }^{\circ} \mathrm{C}$ for all three granite samples, indicating the existence of magnetite and probably maghemite in the Shibei granites. The progressive decrease in the magnetic susceptibility until approximately $680{ }^{\circ} \mathrm{C}$ indicates the presence of hematite, which may be part of the natural mineral assemblage, or, and more likely have been formed during analytical heating from maghemite or magnetite as the cooling curves show relatively weaker susceptibility (Dunlop and Özdemir, 1997). The hysteresis curves show similarly narrow, S-shaped multidomain-like hysteresis loops (Fig. 5d-5f; Suk and Halgedahl, 1996), with little difference between uncorrected and corrected curves (blue and orange lines, respectively, in Fig. 5d-5f), indicating that the magnetic 
property of the granites is dominated by ferromagnetic minerals with little contribution from paramagnetic minerals. The rapid saturation of the magnetic remanence at an applied magnetic field below $400 \mathrm{mT}$ (Fig. 5g) also denotes the presence of ferromagnetic minerals in the granites. As presented in Fig. 5h, the magnetite size in our sample plots in the multi-domain and pseudo-single domains (Hrouda and Jelínek, 1990; Channell and Mccabe, 1994).

In summary, the main magnetic susceptibility carrier in the Shibei granites is magnetite, with probable minor contributions from maghemite and hematite.

\subsubsection{Magnetic parameters}

The magnetic parameters of the measured specimen, such as the bulk magnetic susceptibility $(\mathrm{Km})$, corrected degree of anisotropy $\left(\mathrm{P}_{\mathrm{J}}\right)$, and shape parameter $(\mathrm{T})$, are presented in Table 1 and Fig. 6.

The $\mathrm{Km}$ values range from 0.20 to $274 \times 10^{-3}$ with approximately $70 \%$ of the specimens having $\mathrm{Km}$ values above $10 \times 10^{-3}$, due to the high ferromagnetic minerals content (Fig. 6a and Table 1; Hrouda, 1982). The site-mean values of the corrected degree of anisotropy $\left(\mathrm{P}_{\mathrm{J}}\right)$ vary from 1.01 to 1.28 , and $65 \%$ of sites have $\mathrm{P}_{\mathrm{J}}$ values below 1.10 (Fig. 6b). Furthermore, the $\mathrm{P}_{\mathrm{J}}$ values correlate positively with the $\mathrm{Km}$ values (Fig. $6 \mathrm{~b}$ ), suggesting that the higher $\mathrm{P}_{\mathrm{J}}$ values are probably due to the higher magnetite concentration in the samples (Rochette et al., 1992).

The site-mean values of shape parameter (T) range between -0.11 and 0.69 , except for Site S16 with a T value of -0.6 and other four sites (S10, S12, S21 and S36) with slightly negative $\mathrm{T}$ values, denoting that the majority of the magnetic ellipsoids are characterized by 
oblate geometries (Fig. 6c).

\subsubsection{AMS results for the Shibei pluton}

Following Jelínek and Kropáček (1978), the site-mean directions of the three principal axes of the magnetic ellipsoid (i.e. $K_{1} \geq K_{2} \geq K_{3}$ ) were calculated for each site at the $95 \%$ confidence level (Table 1). The maximum $\left(\mathrm{K}_{1}\right)$ and minimum $\left(\mathrm{K}_{3}\right)$ axes correspond to the magnetic lineation and poles of the magnetic foliation, respectively (Rochette, 1992; Borradaile and Henry, 1997; Fig. 6c). The AMS results of our specimens from the Shibei pluton can be classified into two groups according to their spatial distribution, namely, the southern-central and northern groups (Table 1).

The southern-central group consists of twenty-eight sites and shows consistent magnetic foliations (Fig. 7a). All sites display steep to sub-vertical foliations with dip angles ranging from $54^{\circ}$ to $90^{\circ}$ with a mean value of $74^{\circ}$ (Table 1 and Fig. 7a). Twenty-six sites show NE-SW or NNE-SSW-striking magnetic foliations, and the remaining two sites (S22 and S30) have NW-SE-striking magnetic foliations (Fig. 7a). The magnetic lineations display a predominantly NE-SW trend with variable plunges from horizontal to vertical (Stereograms shown in Fig. 7b).

The northern group includes 9 sites (Sites S01, S02, S03, S04, S33, S34, S35, S36 and S37; gray equal-area projections in Fig. 7a), therein, the outcrops at Sites S01 and S02 are granites exposed by recent urbanization activities in this area. Considering their similar lithologies, and short distance to the main pluton, we consider these two sites as a satellite part of the Shibei pluton. The magnetic fabrics of this group are characterized by pluton-outward dipping magnetic foliations showing variable dip angles ranging from $26^{\circ}$ to 
$88^{\circ}$ with a mean value of $55^{\circ}$, which are generally consistent with the country rock bedding/foliation (Fig. 2a). In addition, the foliation strikes of the majority of sites, except for Sites S37 and S34, are roughly parallel to the granite-country rock boundary (Fig. 7a). In contrast, the trend of the magnetic lineation is more dispersed with respect to that of the southern-central group (Fig. 7c). This kind of magnetic fabric pattern may be attributed to the complicated granite-country rock boundary geometry.

\section{Estimation of the pluton emplacement depth}

Several methods have been proposed to estimate pluton emplacement depth, which remains challenging, such as experimental petrology (Tuttle and Bowen, 1958; Scaillet et al., 2016); the Al-in-hornblende geobarometer (Hammarstrom and Zen, 1986; Johnson and Rutherford, 1989), rhyolite-MELTS phase-equilibrium for silicic magmas (Gualda et al., 2012), titanite barometry (Erdmann et al., 2019) and the Qtz- and (Ab+Or)-geobarometer (Yang, 2017). According to the mineral association of the Late Jurassic granites of the Shibei pluton, the Qtz- and (Ab+Or)-geobarometers were adopted due to a suitable content of normative Qtz ranging from 15 to $40 \mathrm{wt} \%$ (Wang et al., 2016; Yang, 2017). A total of four samples were chosen for our barometric study, i.e. samples SP-4, SP-5, SP-7 and SP-9 (sample locations in Fig. 3; reference data are from Wang et al., 2016). With the whole-rock compositional data, the emplacement pressure conditions are calculated as ranging from 159 to $232 \mathrm{MPa}$ (PQtz) and 150 to $222 \mathrm{MPa}(\mathrm{P}(\mathrm{Ab}+\mathrm{Or})$ ), respectively (Fig. 8). Accordingly, the emplacement depth is estimated at between $4.1 \mathrm{~km}$ and $6.3 \mathrm{~km}$ with a pressure gradient of 2.7 $\mathrm{km} / 100 \mathrm{MPa}$, assuming that an average density of continental crust with $2.7 \mathrm{~g} / \mathrm{cm}^{3}$. Therefore, the Shibei pluton was emplaced at upper continental crust level.5. 


\section{Gravity modelling}

Regional gravity anomalies reflect the density architecture of the underlying geological units; therefore, proper interpretation of gravity anomaly data can help to reveal their boundaries and extent at depth (Améglio et al., 1997; Martelet et al., 2004). Granitic bodies usually have low densities compared to their country rocks and are good candidates for gravity modelling. Indeed, Bouguer gravity modelling has been successfully used to study the geometry of intrusive bodies in the SCB (Feng et al., 2012; Chen et al., 2015; Wei et al., 2016; Ji et al., 2018; Liu et al., 2018). In this study, gravity modelling is applied to reveal the 3-D geometry of the Shibei pluton.

The 1:200,000 original Bouguer gravity anomaly map for the Shibei pluton area was collected from the Chinese Bouguer gravity anomaly database. In addition, regional gravity data for the Fujian Province, covering the Shibei pluton and its surrounding areas, were downloaded from the International Gravity Bureau (http://bgi.omp.obs-mip.fr). Moreover, Digital Elevation Model (DEM) data for the study area with a resolution of $90 \mathrm{~m}$ were obtained from the Shuttle Radar Topography Mission (Farr et al., 2007). A density value of $2.69 \mathrm{~g} / \mathrm{cm}^{3}$ is applied for the uppermost part of the Mayuan Group, country rocks of the Shibei pluton, following information provided by the Fujian Province geological survey (BGMRFP, 1985); a similar density value of $\left(2.73 \mathrm{~g} / \mathrm{cm}^{3}\right.$; Fig. 9a) was used for the strata at the depth of the Mayuan Group and its basement according to the density study of the crustal structure of the SCB by Deng et al. (2014). A density value of $2.62 \mathrm{~g} / \mathrm{cm}^{3}$ is used for the Shibei granites, and it represents an average value for biotite-bearing granites in South China (Liu et al., 2018). The original Bouguer gravity data include local as well as regional and long wavelength 
gravity signals. To obtain more suitable gravity anomaly information produced by shallow geological bodies, we removed the long wavelength signals, which were computed from the regional Bouguer gravity anomaly data of the Fujian Province. Several low-pass Butterworth filters, with cutoff wavelengths of $50 \mathrm{~km}, 70 \mathrm{~km}, 100 \mathrm{~km}$ and $150 \mathrm{~km}$, were applied to the Bouguer gravity data in order to retrieve the residual gravity anomaly by subtraction. Consequently, the residual gravity anomaly data with a cutoff wavelength of $75 \mathrm{~km}$ were chosen for the gravity modelling (Fig. 9a), which gave the best residual anomaly match to the surface geological features, while properly removing long wavelength regional trends.

In the residual Bouguer gravity anomaly map (Fig. 9a), the Shibei pluton displays two negative anomaly centers. The more negative one is located in the southern part of the currently exposed Late Jurassic Shibei pluton. The less negative center is near the middle-western margin of the pluton (Fig. 9a), beneath a relatively small Cretaceous granitic body intruding in the Shibei pluton (BGMRFP, 1985; Wang et al., 2016). According to the regional structural features (the NE-SW trending fold and fault system in the country rocks) and our gravity data, two profiles (AA' and $\left.\mathrm{BB}^{\prime}\right)$ perpendicular to and three profiles (CC', DD' and EE') parallel to the regional geological structures were produced (Fig. 9a). To reduce the ambiguity of the interpreted profiles, a progressive match was achieved on the five profiles by iterating shapes and depths until similar depths were achieved at the intersection of all profiles. The final gravity model accounts for the geophysical, petrophysical and geological constraints.

The interpreted profiles are presented in Fig. $9 \mathrm{~b}$ and four main observations can be summarized as follows: (a) the thickness of the Shibei pluton varies from ca. $2.5 \mathrm{~km}$ in the 
south to $0.5 \mathrm{~km}$ in the north (from profiles BB' to EE' in Fig. 9b) with an average thickness of about $1.5 \mathrm{~km}$; (b) the pluton displays a relatively flat bottom in NE-SW direction (profiles CC', DD' and EE' in Fig. 9b); (c) an overall tabular shape is recognized for the Shibei pluton with a length/width/thickness ratio of 32:8:1; and (d) at the regional scale, a NW-SE oriented negative gravity anomaly belt is observed in the country rocks (Mayuan Group), oblique to the exposure elongation of the Shibei pluton.

\section{Discussion}

\subsection{Implications of the AMS results of the Shibei granites}

Through reviewing previous results and our study in the Shibei area, several features of the Shibei pluton and its country rocks can be summarized as follows: 1) at the regional scale, the Late Jurassic tectonic activity is relatively weak in the Cathaysia Block (Lin et al., 2008; Shu et al., 2009), and regionally consistent syn-magmatism deformation has not been documented either in the study area or in SE China; 2) evidence for ductile deformation is not recognized along the pluton-country rock contact zones; 3) within the pluton, preferred orientation of minerals and/or enclaves is visible neither on the macroscopic nor on the microscopic scale (Figs. 3 and 4); 3) evidence for ductile deformation is not recognized along the contact zones between the pluton and its country rocks; 4) both in hand specimen and under the microscope, typical magmatic textures are well preserved in the Shibei granites, being characterized by euhedral crystals without any high-temperature or high-strain deformation fabrics (Fig. 4); and 5) the Shibei granites demonstrate dominantly low $\mathrm{P}_{\mathrm{J}}$ values $(<1.10)$ (Table 1). Therefore, we propose that the magnetic fabrics of the Shibei granite are magmatic, hence primary, i.e. they were acquired during magma crystallization without 
obvious overprint or reworking by sub- or post-solidus regional tectonic events. Furthermore, magma emplacement most likely occurred during a period of relative tectonic quiescence.

The first predominant feature of the magnetic fabrics of the Shibei pluton is the consistency between the majority of NE-SW-striking magnetic foliations in the southern-central part of the pluton (bold dark gray symbols in Fig. 10a and 10b) and the generally NE-SW-striking fault-and-fold system developed in the country rocks (Fig. 2a), although a few exceptions exist at a few sites mainly located near the northern margin of the pluton, where magnetic foliations gently plunge away from the pluton and striking generally parallel to the pluton-country rock contact (Figs. 7a and 9a). This suggests that the magma emplacement process might be either controlled by the syn-/post-magmatism regional tectonic regime in the NW-SE direction during emplacement or due to guided by the inherited NE-SW-striking structures in the country rock. As mentioned above, the Shibei pluton intrusion occurred during a tectonic quiescent period, thus, the inherited structures produced by the pre-Jurassic and multi-phase regional tectonics might have facilitated and even guided/controlled magma ascent in the Late Jurassic Shibei pluton.

The second significant feature of the magnetic fabric patterns of the Shibei pluton is the obvious difference between the northern and the southern-central parts of the pluton, which suggests an important change of emplacement direction inside the pluton, and further supports that the magma emplacement was mainly controlled by the inherited structures of the country rocks instead of external regional tectonic forces. The main driving force of magma emplacement could therefore have been magma buoyancy. However, the classic diapir-type magma ascent model might not apply to the Shibei pluton since its fabrics and that of its 
country rocks are different from those developed in a typical diapiric intrusion, for example, lacking obvious ductile deformation and metamorphic aureole around the pluton, absent of concordant planar and linear fabrics between the pluton margin and its wall rocks (e.g., Schuiling, 1962; Morgan et al., 2013). Therefore, the magma emplacement process of the Shibei pluton needs to be carefully considered.

\subsection{Space for magma emplacement}

One of the most critical questions in the understanding of the emplacement mechanism of the Shibei pluton is how space was created for magma emplacement without ductile deformation of the country rocks. As mentioned above, the Cathaysia Block was intensively deformed by the multi-stage regional tectonics, associated with the formation of several series of large-scale folds and faults (Fig. 2a). Therefore, Huang (1945) defined the highly deformed crust of the Cathaysia Block as the "South China Fold Belt". The small concentric Bouguer gravity anomaly center in the southwestern corner of the Shibei pluton (Fig. 9a) and its corresponding concave profile (profile $\mathrm{BB}^{\prime}$ in Fig. 9b) may represent an intersection of NE-SW and NW-SE striking structures. Indeed, at the intersections of such variably oriented structures, stress drops and initial magma intrusion is facilitated (Gudmundsson, 1999; Ziv et al., 2000). Furthermore, these conjugate pairs of faults in the brittle upper crust will also facilitate lateral movement (re-arrangement) of the surrounding country rocks to accommodate successively accreted magma batches. The lateral movement of the country rocks may also be further accommodated through the strengthening of ancient folds, and the re-activation of inherited thrusts. Our AMS study suggests that the Shibei pluton was likely constructed by the accumulation of a series of vertical to sub-vertical, NE-SW-striking 
magma injections, which are oblique to the long axis of the overall pluton surface geometry. This phenomenon also suggests lateral movement of the country rocks during magma emplacement. In addition, our geobarometric study shows that the Shibei pluton was emplaced at upper crust level ( 150 to $232 \mathrm{MPa})$, where the crust was previously highly deformed into a mechanically weakened zone with dominantly NE-SW-striking folds and faults, but without developing ductile deformation fabrics. Therefore, the uplift of the country rocks may have naturally accommodated the gradual magma intrusions (e.g., Corry, 1988), although roof erosion does not allow to see this anymore.

In brief, we propose that progressive accretion of magma injections would have dislocated the country rocks sideways. Such a progressive intrusion of magma via many small batches, instead of via a few large batches, may result in step-wise imbrication of country rocks, which in turn would permit accommodation of successive magma arrivals through re-arrangement of the highly fractured upper crust without leading to obvious ductile deformation. However, lateral displacement of country rocks alone may not be enough to accommodate the emplacement of the entire Shibei pluton, and upwelling magma may have also been deflected into sills and intruded along the mechanical discontinuities in the country rocks (e.g., Gudmundsson, 2011). Considering the highly fractured and heterogeneous nature of the upper crust of the Cathaysia Block, discontinuities of the mechanical properties or elastic mismatch are also feasible to induce uplifting and sagging of the country rocks to accommodate the magma arrivals and construct the Shibei pluton, which also supported by the weakly inclined and outward dipping magnetic foliations in the northern part of the pluton. 


\subsection{Magma injection and accretion model for the Shibei pluton}

The dominantly NE-SW-striking and highly inclined magnetic foliations both suggest the existence of planar conduit-fed emplacement of the Shibei pluton (e.g., Ferré et al., 2002). In view of the important pluton volume and our observations of the current exposure described above, the country rocks were not visibly deformed and a significant thermal aureole in the contact zone is absent, the possibility for a single magma tank model can be ruled out. Instead, a multiple magma injection and accretion emplacement model seems more likely. Such a incremental model is often proposed for large-scale plutons (e.g., Deniel et al., 1987; Gudmundsson, 2011; Annen et al., 2015 and references therein), although it is difficult to determine the number of magma intrusions due to the lack of high-resolution geochronological results and lack of exposed intrusive or chill contacts. Indeed, intrusive contacts are rarely discernable inside a pluton, which may reflect non-exposure or erosion of the contact, its thermal annealing (Passchier and Trouw, 1998; Mills and Glazner, 2013), the remelting of the intrusive contact by the subsequent magma pulses (Byerly et al., 2017), later magma injection into the magma mush obscuring the contact (Wiebe et al., 2004; Miller et al., 2011 and references therein), or collapse of the contact into the later homogeneous magma batch, especially for vertically intruded magma batches (Bergantz, 2000). Therefore, the magnetic foliation distribution patterns of the Shibei pluton suggest that the pluton was probably constructed by the accumulation of several magma intrusions instead of one voluminous magma batch.

Additionally, the undulated shape of the pluton revealed by the gravity modelling along profile AA' (Fig. 9b), which is perpendicular to the strike of the regional structures as well as 
to the magnetic foliations, may indicate the existence of various roots feeding the intrusion. In addition, the gravity modelling profiles constructed in NE-SW direction (profiles CC' and DD' in Fig. 9) show a rather constant thickness of the pluton, whereas, the pluton thickness varies in the NW-SE sections. Such variations in the bottom of the Shibei pluton support the interpretation of the juxtaposition and accretion of NE-SW trending magma injections.

Magnetic lineations of granites are usually used to infer magma flow directions during the emplacement (Borradaile and Henry, 1997; de Saint-Blanquat et al., 2001; Talbot et al, 2005; Žák et al., 2007). Sampled sites from the Shibei pluton present dominantly NE-SW-striking magnetic lineations with variable plunges (Fig. 10c and 10d). The steep magnetic lineations (inclination $>60^{\circ}$ ) of sites S10, S11, S13, S22, S27, S31, and S32 from the southern and central parts of the pluton, may indicate the direction of magma flow from the depth (Figs. 7a and 10c). However, most $(\sim 78 \%)$ of the magnetic lineations have plunges lower than $60^{\circ}$, wherein $72 \%$ of the lineations plunge gently $\left(<45^{\circ}\right)$, suggesting that the magma, at nowadays erosional surface, flowed dominantly sub-horizontally (Fig. 10d). These results suggest successive upward injection of the granitic magmas in the southern and central parts of the Shibei pluton and subsequently sub-horizontal spreading along the inherited NE-SW-striking structures.

Exceptionally, two out of 37 sites (S22 and S30, in the center of the Shibei pluton) display NW-SE oriented magnetic foliations parallel to the locally developed NW-SE striking faults observed in the Mayuan group, the country rocks of the Shibei pluton (Fig. 2a). This indicates that the magma emplacement may have been also locally controlled by NW-SE structures developed in the country rocks. 
Combining previous studies on the regional geology, our field and petrographic observations, AMS and gravity modelling results, a model of numerous small-scale magma injections and accretion emplacement is proposed for the Late Jurassic Shibei granitic pluton (Fig. 11). In the following, the magma emplacement processes are reviewed in detail.

Firstly, the progressive northward thinning of the pluton, along with the general northeastward decrease in inclinations of magnetic foliations and magnetic lineation plunges indicate that the magma emplacement was initiated in the southern part of the pluton with planar-shaped magma supply channels (Fig. 11a). Considering the consistent strike of the magnetic foliation with the regional structures and the absence of syn-magmatic regional tectonics, magma ascent appears to have been mainly driven by magma buoyancy forces and was facilitated by mechanically weak zones in the upper crust, such as the inherited NE-SW-striking high angle to sub-vertical fold and fault structures developed in the Proterozoic Mayuan Group by multi-stage tectonic events (Fig. 10a).

Secondly, the successive arrivals of small magma batches gradually accreted to the previously emplaced magma injections and slightly dislocating the country rocks to continuously create space for subsequent magma emplacement. This process would have modified, and perhaps amplified, the geometry of fold and fault structures in the country rocks, in other words, magma intrusion may have induced local re-arrangement of the inherited structures in the brittle upper crust. However, as no thermal aureole or ductile deformation have been observed in the contact zone, the volume of each intrusion was likely limited (Fig. 11b).

Thirdly, due to the mechanical discontinuity of the "cold and stiff" upper crust, injected 
small magma batches also concordantly flowed along sub-horizontal, NE-SW-trending lithological discontinuities in country rocks (Fig. 11c).

Our study stresses the importance of inherited structures in the country rocks in the assembly of the Shibei pluton. Yet further studies are needed to improve our understanding, such as more precise estimates of pluton emplacement depth, the understanding of rheological modification of the country rocks by magma injections, and the quantitative strain analysis (systematic finite strain and electron backscatter diffraction measurements) of the country rocks.

\section{Conclusions}

(1) Our field investigations, thin section observations and magnetic fabric analyses show that the Late Jurassic Shibei pluton in the Cathaysia Block is texturally isotropic and homogeneous, showing no lithological zonation or preferred mineral orientation. Therefore, the fabrics of the studied pluton can be considered as primary.

(2) Consistent NE-SW-striking, high-angle to vertical magnetic foliations revealed in the southern and central parts of the Shibei pluton are parallel to the strikes of regional fold and fault structures of the country rocks; the plunges of the corresponding magnetic lineations are highly variable. The magnetic foliations in the northern part of the pluton are concordant with the beddings or the foliations of the country rocks with dispersed magnetic lineations.

(3) The gravity modelling reveals that the Shibei pluton has a tabular shape with a gradual thinning from the south $(2.5 \mathrm{~km})$ to the north $(0.5 \mathrm{~km})$. By contrast, the thickness of the pluton in the NE-SW direction is relatively constant.

(4) On the basis of an integrated analysis of available data, we suggest that the Late 
Jurassic Shibei pluton was constructed by successive NE-SW striking small-scale magma injections, which were supplied from the southern part of the pluton and accreted laterally in the NW-SE direction. Due to the lack of syn-magmatic regional tectonics, we infer that magma emplacement was driven by magma buoyancy forces, while the inherited structures in the country rocks (folds and faults formed by multi-stage pre-Jurassic tectonic events) may have facilitated and guided the magma ascent.

\section{Acknowledgements}

We thank Mrs. France Lagroix from the Institut de Physique du Globe de Paris for her help in hysteresis loop measurements, Dr. Guochang Wang for discussions about granites of the Shibei pluton, and Dr. Chaolei Yan for his help in sample collection. The constructive and thorough reviews and comments from Dr. Jirí Žák, Dr. Eric Ferré and Editor Philippe Agard are highly appreciated. This study was supported by the National Basic Research Program of China (973 Program, 2012CB416701) and the Open Fund of State Key Laboratory for Mineral Deposits Research of Nanjing University (ZZKT-201603), as well as French research programs Labex Voltaire and Equipex planex. In particular, a 3-year scholarship from the French Ministry of Higher Education and Research (MESR) to the first author is gratefully acknowledged.

\section{References}

Allibon, J., Bussy, F., Lewin, E., Darbellay, B., 2011. The tectonically controlled 
emplacement of a vertically sheeted gabbro-pyroxenite intrusion: feeder-zone of an ocean-island volcano (Fuerteventura, Canary Islands). Tectonophysics 500(1), 78-97.

Améglio, L., Vigneresse, J.L., Bouchez, J.L., 1997. Granite Pluton Geometry and Emplacement Mode Inferred from Combined Fabric and Gravity Data, in: Bouchez, J.L., Hutton, D.H.W., Stephens, W.E. (Eds.), Granite: From Segregation of Melt to Emplacement Fabrics. Springer Netherlands, Dordrecht, pp. 199-214.

Annen, C., Blundy, J., Sparks, R., 2006. The genesis of intermediate and silicic magmas in deep crustal hot zones. Journal of Petrology 47(3), 505-539.

Annen, C., Blundy, J.D., Leuthold, J., Sparks, R.S.J., 2015. Construction and evolution of igneous bodies: Towards an integrated perspective of crustal magmatism. Lithos 230, 206-221.

Bateman, R., 1984. On the role of diapirism in the, segregation, ascent and final emplacement of granitoid magmas. Tectonophysics 110(3-4), 211-231.

Bergantz, G.W., 2000. On the dynamics of magma mixing by reintrusion: implications for pluton assembly processes. Journal of Structural Geology 22, 1297-1309.

BGMRFP (Bureau of Geology and Mineral Resources of Fujian Province), 1985. Regional Geology of the Jiangxi Province Geological Publishing House, Beijing, 675 pp.

Blundy, J.D., Annen, C.J., 2016. Crustal magmatic systems from the perspective of heat transfer. Elements 12(2), 115-120.

Borradaile, G. J., Kehlenbeck, M. M., 1996. Possible cryptic tectono-magnetic fabrics in 'post-tectonic'granitoid plutons of the Canadian Shield. Earth and Planetary Science Letters 137(1-4), 119-127. 
Borradaile, G. J., Henry, B., 1997. Tectonic applications of magnetic susceptibility and its anisotropy, Earth-Science Reviews 42(1), 49-93.

Brown, E. H., Mcclelland, W. C., 2000. Pluton emplacement sheeting and vertical ballooning in part of the southeast coast plutonic complex, british columbia. Geological Society of America Bulletin 112(5), 708-719.

Burchardt, S., 2008. New insights into the mechanics of sill emplacement provided by field observations of the Njardvik Sill, Northeast Iceland. Journal of Volcanology and Geothermal Research 173(3), 280-288.

Byerly, A., Tikoff, B., Kahn, M., Jicha, B., Gaschnig, R., Fayon, A.K., 2017. Internal fabrics of the Idaho batholith, USA. Lithosphere 9, 283-298.

Channell, J.E.T., Mccabe, C., 1994. Comparison of magnetic hysteresis parameters of unremagnetized and remagnetized limestones. Journal of Geophysical Research Solid Earth 99, 4613-4623.

Charvet, J., Shu, L., Faure, M., Choulet, F., Wang, B., Lu, H., and Le Breton, N., 2010. Structural development of the Lower Paleozoic belt of South China: genesis of an intracontinental orogen. Journal of Asian Earth Sciences 39(4), 309-330.

Chen, G., Liu, T., Sun, J., Cheng, Q., Sahoo, B., Zhang, Z., Zhang, H., 2015. Gravity method for investigating the geological structures associated with $\mathrm{W}-\mathrm{Sn}$ polymetallic deposits in the Nanling Range, China. Journal of Applied Geophysics 120, 14-25.

Chen, J., Jahn B.-m., 1998. Crustal evolution of southeastern China: Nd and Sr isotopic evidence. Tectonophysics 284(1), 101-133.

Chen, C.-H., Lee, C.-Y., Liu, Y.-H., Xiang, H., Zeng, W., Zhou, H.-W., 2018. Precambrian 
protoliths and Phanerozoic overprinting on the Wuyishan terrain (South China): New evidence from a combination of LA-ICPMS zircon and EMP monazite geochronology. Precambrian Research 307, 229-254.

Chu, Y., Lin, W., 2018. Strain analysis of the Xuefengshan Belt, South China: From internal strain variation to formation of the orogenic curvature. Journal of Structural Geology 116, 131-145.

Chu, Y., Faure, M., Lin, W., and Wang, Q. C., 2012a. Early Mesozoic tectonics of the South China block: Insights from the Xuefengshan intracontinental orogen. Journal of Asian Earth Sciences 61, 199-220.

Chu, Y., Faure, M., Lin, W., Wang, Q.C., and Ji, W.B., 2012b. Tectonics of the Middle Triassic intracontinental Xuefengshan Belt, South China: new insights from structural and chronological constraints on the basal décollement zone, International Journal of Earth Sciences, 101(8), 2125-2150.

Corry, C. E., 1988. Laccoliths: mechanics of emplacement and growth (Vol. 220). Geological Society of America.

Cruden, A. R., 1990. Flow and fabric development during the diapiric rise of magma. The Journal of Geology 98(5), 681-698.

Daly, R. A., 1903. The mechanics of igneous intrusion. American Journal of Science (88), 269-298.

de Saint-Blanquat, M., Law, R.D., Bouchez, J.L., Morgan, S.S., 2001. Internal structure and emplacement of the Papoose Flat pluton: An integrated structural, petrographic, and magnetic susceptibility study. Geological Society of America Bulletin 113, 976-995. 
de Saint-Blanquat, M., Habert, G., Horsman, E., Morgan, S. S., Tikoff, B., Launeau, P.,

Gleizes, G., 2006. Mechanisms and duration of non-tectonically assisted magma emplacement in the upper crust: the Black Mesa pluton, Henry Mountains, Utah. Tectonophysics 428 (1), 1-31.

de Saint-Blanquat, M., Horsman, E., Habert, G., Morgan, S., Vanderhaeghe, O., Law, R., Tikoff, B., 2011. Multiscale magmatic cyclicity, duration of pluton construction, and the paradoxical relationship between tectonism and plutonism in continental arcs. Tectonophysics 500(1), 20-33.

Deng Y.F., Zhang Z.J., José B., Fan W.M., 2014. 3-D density structure under South China constrained by seismic velocity and gravity data. Tectonophysics 627, 159-170.

Deniel, C., Vidal, P., Fernandez, A., Le Fort, P., Peucat, J.J., 1987. Isotopic study of the Manaslu granite (Himalaya, Nepal): inferences on the age and source of Himalayan leucogranites. Contributions to Mineralogy and Petrology 96, 78-92.

Dixon, J. M., 1975. Finite strain and progressive deformation in models of diapiric structures. Tectonophysics 28(1-2), 89-124.

Douce, A.E.P.O., Humphreys, E.D., Johnston, A.D., 1990. Anatexis and metamorphism in tectonically thickened continental crust exemplified by the Sevier hinterland, western North America. Earth and Planetary Science Letters 97, 290-315.

Dunlop, D.J., Özdemir, Ö., 1997. Rock Magnetism: Fundamentals and Frontiers. Cambridge University Press, Cambridge, 596 pp.

Erdmann, S., Wang, R.C., Huang, F.F., Scaillet, B., Zhao, K., Liu, H.S., Chen, Y., Faure, M., 2019. Titanite: A potential solidus barometer for granitic magma systems. Comptes 
Rendus Geoscience 351(8), 551-561.

Farr, T.G., Rosen, P.A., Caro, E., Crippen, R., Duren, R., Hensley, S., Kobrick, M., Paller, M., Rodriguez, E., Roth, L., 2007. The shuttle radar topography mission. Reviews of geophysics 45 .

Faure, M., Shu, L.S., Wang, B., Charvet, J., Choulet, F., Monie, P., 2009. Intracontinental subduction: A possible mechanism for the Early Palaeozoic Orogen of SE China. Terra Nova 21, 360-368.

Faure, M., Lin, W., Chu, Y., and Lepvrier, C., 2016. Triassic tectonics of the southern margin of the South China Block. Comptes Rendus Geoscience 348(1), 5-14.

Feng, Z., Wang C.Z., M. Zhang, M.H., Liang, J.C., 2012. Unusually dumbbell-shaped Guposhan-Huashan twin granite plutons in Nanling Range of south China: Discussion on their incremental emplacement and growth mechanism. Journal of Asian Earth Sciences $48,9-23$.

Ferré, E., Gleizes, G., Djouadi, M.T., Bouchez, J.L., Ugodulunwa, F.X.O., 1997. Drainage and emplacement of magmas along an inclined transcurrent shear zone: petrophysical evidence from a granite-charnockite pluton (Rahama, Nigeria). In: Bouchez, J.L., Hutton, D.H.W., Stephens, W.E. (Eds), Granite: From Segregation of Melt to Emplacement Fabrics. Kluwer Publishing Co, Dordrecht, pp. 253-273.

Ferré, E.C., Améglio, L., 2000. Preserved magnetic fabrics vs. annealed microstructures in the syntectonic recrystallised George granite, South Africa. Journal of Structural Geology 22(8), 1199-1219.

Ferré, E.C., Bordarier, C., Marsh, J.S., 2002. Magma flow inferred from AMS fabrics in a 
layered mafic sill, Insizwa, South Africa. Tectonophysics 354, 1-23.

Gilder, S. A., Coe, R. S., Wu, H., Kunag, G., Zhao, X., Wu, Q., 1995. Triassic paleomagnetic data from south China and their bearing on the tectonic evolution of the western circum-Pacific region. Earth and Planetary Science Letters 131(3-4), 269-287.

Glazner, A. F., Bartley, J. M., 2006. Is stoping a volumetrically significant pluton emplacement process?. Geological Society of America Bulletin, 118(9-10), 1185-1195.

Glazner, A. F., 2007. Thermal limitations on incorporation of wall rock into magma. Geology, 35(4), 319-322.

Grabau, A.W., 1924. Stratigraphy of China, Part I, Paleozoic and Older. Geological Survey of Agriculture and Commence, Peking, 528 pp.

Gualda, G.A.R., Ghiorso, M.S., Lemons, R.V., Carley, T.L., 2012. Rhyolite-MELTS: a modified calibration of MELTS optimized for silica-rich, fluid-bearing magmatic systems. Journal of Petrology 53, 875-890.

Gudmundsson, A., 1999. Fluid overpressure and stress drop in fault zones. Geophysical Research Letters 26, 115-118.

Gudmundsson, A., 2011. Deflection of dykes into sills at discontinuities and magma-chamber formation. Tectonophysics 500(1), 50-64.

Guo, L.Z., Shi, Y.S., Lu, H.F., Ma, R.S., Dong, H.G., Yang, S.F., 1989. The pre-Devonian tectonic patterns and evolution of south china. Journal of Southeast Asian Earth Sciences 3(1), 87-93.

Guo, L.Z., Shi, Y.S., Ma, R.S., 1980. The geotectonic framework and crustal evolution of South China. In: Guo, L.Z. (Ed.), The plate tectonics of South China. Geological 
Publishing House, Beijing, pp. 1-264 (in Chinese).

Hammarstrom, J.M., Zen, E-An, 1986. Aluminium in hornblende: an empirical igneous geobarometer. American Mineralogist 71, 1297-1313.

Hrouda, F., 1982. Magnetic anisotropy of rocks and its application in geology and geophysics. Geophysical surveys 5, 37-82.

Hrouda, F., Jelínek, V., 1990. Resolution of ferrimagnetic and paramagnetic anisotropies in rocks, using combined low - field and high - field measurements[J]. Geophysical Journal International 103(1): 75-84.

Huang, J., 1945. On Major Tectonic Forms of China, National Geological Survey of China under the Ministry of Economic Affairs.

Huber, C., Bachmann, O., Dufek, J., 2011. Thermo-mechanical reactivation of locked crystal mushes: Melting-induced internal fracturing and assimilation processes in magmas. Earth and Planetary Science Letters 304(3), 443-454.

Hutton, D.H.W., 1988. Granite emplacement mechanisms and tectonic controls: inferences from deformation studies. Earth and Environmental Science Transactions of the Royal Society of Edinburgh 79, 245-255.

Iyer, H. M., 1984. Geophysical evidence for the locations, shapes and sizes, and internal structures of magma chambers beneath regions of Quaternary volcanism. Philosophical Transactions of the Royal Society of London. Series A, Mathematical and Physical Sciences 310(1514), 473-510.

Jelínek, V., Kropáček, V., 1978. Statistical processing of anisotropy of magnetic susceptibility measured on groups of specimens. Studia Geophysica et Geodaetica 22, 50-62. 
Ji, W., Chen, Y., Chen, K., Wei, W., Faure, M., Lin, W., 2018. Multiple Emplacement and Exhumation History of the Late Mesozoic Dayunshan-Mufushan Batholith in Southeast China and Its Tectonic Significance: 2. Magnetic Fabrics and Gravity Survey. Journal of Geophysical Research: Solid Earth 123, 711-731.

Johnson, M.C., Rutherford, M.J., 1989. Experimental calibration of the aluminum-in hornblende geobarometer with application to Long Valley caldera (California) volcanic rocks. Geology 17, 837-841.

Li, J.H., Zhang, Y.Q., Dong, S.W., Johnston S.T., 2014. Cretaceous tectonic evolution of South China: A preliminary synthesis. Earth-Science Reviews 134: 98-136.

Li, J., Zhang, Y., Zhao, G., Johnston, S.T., Dong, S., Koppers, A., Miggins, D.P., Sun, H., Wang, W., Xin, Y., 2017. New insights into Phanerozoic tectonics of South China: Early Paleozoic sinistral and Triassic dextral transpression in the east Wuyishan and Chencai domains, NE Cathaysia. Tectonics 36.

Li, L.M., Sun, M., Wang, Y.J., Xing, G.F., Zhao, G.C., Cai, K.D., Zhang, Y.Z., 2011. Geochronology and geochemistry of Palaeoproterozoic gneissic granites and clinopyroxenite enclaves from NW Fujian, SE China: implications for the crustal evolution of the Cathaysia Block. J. Asia Earth Sci. 41, 204-212.

Li, X.H., 1997. Timing of the Cathaysia block formation: constraints from SHRIMP U-Pb zircon geochronology. Episodes 20, 188-192.

Li, X.H., Chen, Z.G., Liu, D.Y., Li, W.X., 2003. Jurassic gabbro-granite-syenite suites from southern Jiangxi Province (SE China): age, origin and tectonic significance. International Geology Review 45, 898 - 921. 
Li, Z.X., Kinny, P.D., 2002. Grenvillian continental collision in South China: new SHRIMP $\mathrm{U}-\mathrm{Pb}$ zircon results and implications for the configuration of Rodinia. Geology 30, 163-166.

Li, Z.X., Bogdanova, S.V., Collins, A.S., Davidson, A., Waele, B.D., Ernst, R.E., Fitzsimons, I.C.W., Fuck, R.A., Gladkochub, D.P., Jacobs, J., Karlstrom, K.E., Lu, S., Natapov, L.M., Pease, V., Pisarevsky, S.A., Thrane, K., Vernikovsky, V., 2008. Assembly, configuration, and break-up history of Rodinia: A synthesis. Precambrian Research 160, 179-210.

Li, Z.-X., Li, X.-H., Wartho, J.-A., Clark, C., Li, W.-X., Zhang, C.-L., Bao, C., 2010. Magmatic and metamorphic events during the early Paleozoic Wuyi- Yunkai orogeny, southeastern South China: New age constraints and pressure-temperature conditions. Bulletin 122, 772-793.

Lin, W., Wang, Q., Chen, K., 2008. Phanerozoic tectonics of south China block: New insights from the polyphase deformation in the Yunkai massif. Tectonics 27(6).

Liu, H., Martelet, G., Wang, B., Erdmann, S., Chen, Y., Faure, M., Huang, F., Scaillet, B., le-Breton, N., Shu, L., Wang, R., Zhu, J., 2018. Incremental Emplacement of the Late Jurassic Midcrustal, Lopolith-Like Qitianling Pluton, South China, Revealed by AMS and Bouguer Gravity Data. Journal of Geophysical Research: Solid Earth 123, 9249-9268.

Liu, R., Zhou, H.W., Zhang, L., Zhong, Z.Q., Zeng, W., Xiang, H., Jin, S., Lu, X.Q., Li, C.Z., 2010. Zircon $\mathrm{U}-\mathrm{Pb}$ ages and $\mathrm{Hf}$ isotope compositions of the Mayuan migmatite complex, NW Fujian Province, Southeast China: Constraints on the timing and nature of a regional tectonothermal event associated with the Caledonian orogeny. Lithos 119, 163-180. 
Maes, S. M., Tikoff, B., Ferré, E. C., Brown, P. E., \& Miller Jr, J. D., 2007. The Sonju Lake layered intrusion, northeast Minnesota: Internal structure and emplacement history inferred from magnetic fabrics. Precambrian Research 157(1-4), 269-288.

Martelet, G., Calcagno, P., Gumiaux, C., Truffert, C., Bitri, A., Gapais, D., Brun, J.P., 2004. Integrated 3D geophysical and geological modelling of the Hercynian Suture Zone in the Champtoceaux area (south Brittany, France). Tectonophysics 382, 117-128.

Mathieu, L., De Vries, B. V. W., Holohan, E. P., Troll, V. R., 2008. Dykes, cups, saucers and sills: Analogue experiments on magma intrusion into brittle rocks. Earth and Planetary Science Letters 271(1), 1-13.

Menand, T., de Saint-Blanquat, M., Annen, C., 2011. Emplacement of magma pulses and growth of magma bodies Emplacement of magma pulses and growth of magma bodies. Tectonophysics 500(1-4), 1-2.

Miller, C.F., Furbish, D.J., Walker, B.A., Clairborne, L.L., Cotheas, G.C., Bleick, H.A., Miller, J.S., 2011. Growth of plutons by incremental emplacement of sheets in crystal-rich host: evidence from Miocene intrusions of the Colorado River region, Nevada, USA. Tectonophysics 500, 65-77.

Mills, R.D., Glazner, A.F., 2013. Experimental study on the effects of temperature cycling on coarsening of plagioclase and olivine in an alkali basalt. Contributions to Mineralogy and Petrology 166, 97-111.

Morgan, J., McGovern, P.J., 2005. Discrete element simulations of gravitational volcanic deformation: 1. Deformation structures and geometries. Journal of Geophysical Research: Solid Earth 110(B5). 
Morgan, S., Law, R., de Saint-Blanquat, M., 2013. Forceful emplacement of the Eureka Valley-Joshua Flat-Beer Creek composite pluton into a structural basin in eastern California; internal structure and wall rock deformation. Tectonophysics 608, 753-773.

Passchier, C. W., Trouw, R. A., 1998. Deformation Mechanisms, in Microtectonics, edited, pp. 25-56, Springer.

Paterson, S.R., Vernon, R.H., Tobisch, O.T., 1989. A review of criteria for the identification of magmatic and tectonic foliations in granitoids. Journal of Structural Geology 11, 349-363.

Paterson, S.R., Vernon, R.H., 1995. Bursting the bubble of ballooning plutons: A return to nested diapirs emplaced by multiple processes. Geological Society of America Bulletin $107,1356-1380$.

Paterson, S. R., Pignotta, G. S., Farris, D., Memeti, V., Miller, R. B., Vernon, R. H., Žák, J., 2008. Is stoping a volumetrically significant pluton emplacement process?: Discussion. Geological Society of America Bulletin 120(7-8), 1075-1079.

Polyansky, O.P., Babichev, A.V., Korobeynikov, S.N., \& Reverdatto, V.V., 2010. Computer modeling of granite gneiss diapirism in the earth's crust: controlling factors, duration, and temperature regime. Petrology 18(4), 432-446.

Pitcher, W.S., 1979. The nature, ascent and emplacement of granitic magmas. Journal of the Geological Society 136, 627-662.

Ren, J., Tamaki, K., Li, S., Junxia, Z., 2002. Late Mesozoic and Cenozoic rifting and its dynamic setting in Eastern China and adjacent areas. Tectonophysics 344, 175-205.

Ren, J., Li, C., 2016. Cathaysia Old Land and Relevant Problems: Pre-Devonian Tectonics of 
Southern China. Acta Geologica Sinica, 90, 607-614 (in Chinese with English abstract).

Roberts, J.L., 1970. The intrusion of magma into brittle rocks. Mechanism of igneous intrusion, 2, 287-338.

Rochette, P., Jackson, M., Aubourg, C., 1992. Rock magnetism and the interpretation of anisotropy of magnetic susceptibility. Reviews of Geophysics 30, 209-226.

Roman, A., Jaupart, C., 2016. The fate of mafic and ultramafic intrusions in the continental crust. Earth and Planetary Science Letters 453, 131-140.

Rubin, A. M., 1993. On the thermal viability of dikes leaving magma chambers. Geophysical Research Letters 20(4), 257-260.

Scaillet, B., Pêcher, A., Rochette, P., Champenois, M., 1995. The Gangotri granite (Garhwal Himalaya): Laccolithic emplacement in an extending collisional belt. Journal of Geophysical Research 100(B1), 585(585-608).

Scaillet, B., Holtz, F., Pichavant, M., 2016. Experimental constraints on the formation of silicic magmas. Elements 12, 109-114.

Schofield, N.J., Brown, D.J., Magee, C., Stevenson, C.T., 2012. Sill morphology and comparison of brittle and non-brittle emplacement mechanisms. Journal of the Geological Society $169(2), 127-141$.

Schuiling, R., 1962. On petrology, age and structure of the Menderes migmatite complex (SW-Turkey). Bulletin of the Mineral Research and Exploration Institute of Turkey 58, $71-84$.

Shu, L., Charvet, J., 1996. Kinematics and geochronology of the Proterozoic Dongxiang-Shexian ductile shear zone: with HP metamorphism and ophiolitic melange 
(Jiangnan Region, South China). Tectonophysics 267, 291-302.

Shu, L.S., Zhou, X.M., Deng, P., Wang, B., Jiang, S.Y., Yu, J.H., Zhao, X.X., 2009. Mesozoic tectonic evolution of the Southeast China Block: New insights from basin analysis. Journal of Asian Earth Sciences 34, 376-391.

Shu, L.S., Faure, M., Yu, J.H., Jahn, B.M., 2011. Geochronological and geochemical features of the Cathaysia block (South China): New evidence for the Neoproterozoic breakup of Rodinia. Precambrian Research 187, 263-276.

Shu, L.S., Jahn, B.M., Charvet, J., Santosh, M., Wang, B., Xu, X.S., Jiang, S.Y., 2014. Early Paleozoic depositional environment and intraplate tectono-magmatism in the Cathaysia Block (South China): Evidence from stratigraphic, structural, geochemical and geochronological investigations. American Journal of Science 314, 154-186.

Shu L.S., Wang B., Cawood P.A., Santosh M., Xu Z.Q., 2015. Early Paleozoic and Early Mesozoic intraplate tectonic and magmatic events in the Cathaysia Block, south China. Tectonics 34 (2015), pp. 1600-1621.

Suk, D., Halgedahl, S. L., 1996. Hysteresis properties of magnetic spherules and whole rock specimens from some Paleozoic platform carbonate rocks. Journal of Geophysical Research: Solid Earth 101(B11), 25053-25075.

Sylvester, P.J., Liegeois, J.P., 1998. Post-collisional strongly peraluminous granites. Lithos 45, $29-44$.

Talbot, J. Y., Chen, Y., Faure, M., 2005. A magnetic fabric study of the Aigoual-Saint Guiral-Liron granite pluton (French Massif Central) and relationships with its associated dikes. Journal of Geophysical Research: Solid Earth 110(B12). 
Tikoff, B., de Saint Blanquat, M., Teyssier, C., 1999. Translation and the resolution of the pluton space problem. Journal of Structural Geology 21(8), 1109-1117.

Tuttle, O.F., Bowen, N.L., 1958. Origin of granite in the light of experimental studies in the system NaAlSi3O8-KAl Si3O8-SiO2-H2O. Geological Society of America Memoirs 74 (153 pp.).

Wang, B., Shu, L., Faure, M., Jahn, B. M., Lo, C. H., Charvet, J., Liu, H., 2014. Phanerozoic Multistage Tectonic Rejuvenation of the Continental Crust of the Cathaysia Block: Insights from Structural Investigations and Combined Zircon U-Pb and Mica 40Ar/39Ar Geochronology of the Granitoids in Southern Jiangxi Province. The Journal of Geology 122(3), 309-328.

Wang D., Zheng J.P., Ma Q., Griffin W.L., Zhao H., Wong J., 2013a. Early Paleozoic crustal anataxis in the intraplate Wuyi-Yunkai orogen, South China. Lithos 175-176: 124-145.

Wang, G. C., Jiang, Y. H., Liu, Z., Ni, C. Y., Qing, L., Zhang, Q., Zhu, S. Q., 2016. Multiple origins for the Middle Jurassic to Early Cretaceous high-K calc-alkaline I-type granites in northwestern Fujian province, SE China and tectonic implications. Lithos 246, 197-211.

Wang, H.Z., Mo, X.X., 1995. An outline of the tectonic evolution of China. Episodes 18 (1-2), 6-16.

Wang J., Li Z.X., 2003. History of Neoproterozoic rift basins in South China: implications for Rodinia break-up. Precambrian Research 122 (1-4): 141-158.

Wang, Q., Zhao, Z.H., Xu, J.F., Bao, Z.W., Ma, J.L., 2004. SHRIMP zircon geochronology and Nd-Sr isotopic geochemistry of the Dexing granodiorite porphyrite. Acta Petrologica Sinica 20 (2), 315-324. 
Wang, Q., Li, J.W., Jian, P., Zhao, Z.H., Xiong, X.L., Bao, Z.W., Xu, J.F., Li, C.F., Ma, J.L., 2005. Alkaline syenites in eastern Cathaysia (South China): link to Permian-Triassic transtension. Earth and Planetary Science Letters 230, 339-354.

Wang, Y.J., Fan, W.M., Guo, F., Peng, T.P., Li, C.W., 2003. Geochemistry of Mesozoic mafic rocks around the Chenzhou-Linwu fault in South China: implication for the lithospheric boundary between the Yangtze and the Cathaysia Blocks. International Geology Review 45 (3), 263-286.

Wang, Y., Zhang, F., Fan, W., Zhang, G., Chen, S., Cawood, P. A., and Zhang, A., 2010. Tectonic setting of the South China Block in the early Paleozoic: Resolving intracontinental and ocean closure models from detrital zircon $\mathrm{U}-\mathrm{Pb}$ geochronology, Tectonics 29(6).

Wang, Y., Wu, C., Zhang, A., Fan, W., Zhang, Y., Zhang, Y., Peng, T., Yin, C., 2012. Kwangsian and Indosinian reworking of the eastern South China Block: Constraints on zircon $\mathrm{U}-\mathrm{Pb}$ geochronology and metamorphism of amphibolites and granulites. Lithos $150,227-242$.

Wang, Y., Fan, W., Zhang, G., Zhang, Y., 2013b. Phanerozoic tectonics of the South China Block: key observations and controversies. Gondwana Research 23(4), 1273-1305.

Wei, W., Chen, Y., Faure, M., Shi, Y.H., Martelet, G., Hou, Q.L., Lin, W., Le Breton, N., Wang, Q.C., 2014. A multidisciplinary study on the emplacement mechanism of the Qingyang-Jiuhua Massif in Southeast China and its tectonic bearings. Part I: Structural geology, AMS and paleomagnetism. Journal of Asian Earth Sciences 86, 76-93.

Wei, W., Chen, Y., Faure, M., Martelet, G., Lin, W., Wang, Q., Yan, Q., Hou, Q., 2016. An 
early extensional event of the South China Block during the Late Mesozoic recorded by the emplacement of the Late Jurassic syntectonic Hengshan Composite Granitic Massif (Hunan, SE China). Tectonophysics 672-673, 50-67.

Weinberg, R.F., 1999. Mesoscale pervasive felsic magma migration: alternatives to dyking. Lithos 46(3), 393-410.

Wiebe, R.A., Manon, M.R., Hawkins, D.P., McDonough, W.F., 2004. Late-stage mafic injection and thermal rejuvenation of the Vinalhaven Granite, Coastal Maine. Journal of Petrology 45, 2133-2153.

Xia, Y., Xu, X.S., Zhu, K.Y., 2012. Paleoproterozoic S- and A-type granites in southwestern Zhejiang: magmatism, metamorphism and implications for the crustal evolution of the Cathaysia basement. Precambrian Res. 216-219, 177-207.

Xiang, H., Zhang, L., Zhou, H.W., Zhong, Z.Q., Zeng, W., Liu, R., Jin, S., 2008. U-Pb zircon geochronology and Hf isotope study of metamorphosed basic-ultrabasic rocks from metamorphic basement in southwestern Zhejiang: the response of the Cathaysia Block to Indosinian orogenic event. Sci. China, Ser. D Earth Sci. 51, 788-800.

Xie Douke, Ma Rongsheng, Zhang Yushen. 1996. The Crust Growth and Mantale Plume Tectonics of South China Continent[M]. Beijing: Geological Press, 1996.

Xu, X. B., Zhang, Y. Q., Shu, L. S., Jia, D., 2011. La-ICP-MS U-Pb and ${ }^{40} \mathrm{Ar} /{ }^{39} \mathrm{Ar}$ geochronology of the sheared metamorphic rocks in the Wuyishan: Constraints on the timing of Early Paleozoic and Early Mesozoic tectono-thermal events in SE China. Tectonophysics 501(1), 71-86.

Xu, X., Li, Y., Tang, S., Xue, D., Zhang, Z., 2015. Neoproterozoic to Early Paleozoic 
polyorogenic deformation in the southeastern margin of the Yangtze Block: Constraints from structural analysis and 40Ar/39Ar geochronology. Journal of Asian Earth Sciences 98, 141-151.

Yang, X-M., 2017. Estimation of crystallization pressure of granite intrusions. Lithos 286-287: 324-39.

Yao, J., Shu, L., Santosh, M., 2011. Detrital zircon U-Pb geochronology, Hf-isotopes and geochemistry-New clues for the Precambrian crustal evolution of Cathaysia Block, South China. Gondwana Research 20, 553-567.

Yao, J., Shu, L., Cawood, P.A., Li, J., 2016. Delineating and characterizing the boundary of the Cathaysia Block and the Jiangnan orogenic belt in South China. Precambrian Research 275, 265-277.

Yu, J.-H., Wang, L., O’Reilly, S. Y., Griffin, W. L., Zhang, M., Li, C., and Shu, L., 2009. A Paleoproterozoic orogeny recorded in a long-lived cratonic remnant (Wuyishan terrane), eastern Cathaysia Block, China, Precambrian Research 174(3-4), 347-363.

Yu, J. H., O’Reilly, S. Y., Wang, L., Griffin, W. L., Zhou, M. F., Zhang, M., Shu, L., 2010. Components and episodic growth of Precambrian crust in the Cathaysia Block, South China: evidence from $\mathrm{U}-\mathrm{Pb}$ ages and $\mathrm{Hf}$ isotopes of zircons in Neoproterozoic sediments. Precambrian Research 181(1), 97-114.

Žák, J., Paterson, S.R., Memeti, V., 2007. Four magmatic fabrics in the Tuolumne batholith, central Sierra Nevada, California (USA): Implications for interpreting fabric patterns in plutons and evolution of magma chambers in the upper crust. Geological Society of America Bulletin 119, 184-201. 
Žák, J., Verner, K., Tomek, F., Johnson, K., \& Schwartz, J. J., 2017. Magnetic fabrics of arc plutons reveal a significant Late Jurassic to Early Cretaceous change in the relative plate motions of the Pacific Ocean basin and North America. Geosphere 13, 11-21.

Zhang, G., Guo, A., Wang, Y., Li, S., Dong, Y., Liu, S., He, D., Cheng, S., Lu, R., Yao, A., 2013. Tectonics of South China continent and its implications. Science China Earth Sciences 56, 1804-1828.

Zhang, K.-J., Cai, J.-X., 2009. NE-SW-trending Hepu-Hetai dextral shear zone in southern China: Penetration of the Yunkai Promontory of South China into Indochina. Journal of Structural Geology 31, 737-748.

Zhang, Z. M., Liou, J. G., \& Coleman, R. G., 1984. An outline of the plate tectonics of China. Geological Society of America Bulletin 95(3), 295-312.

Zhao, G., Cawood, P. A., 1999. Tectonothermal evolution of the Mayuan Assemblage in the Cathaysia Block; implications for Neoproterozoic collision-related assembly of the South China Craton. American Journal of Science 299(4), 309-339.

Zhao, G., Wang, Y., Huang, B., Dong, Y., Li, S., Zhang, G., \& Yu, S., 2018. Geological reconstructions of the East Asian blocks: From the breakup of Rodinia to the assembly of Pangea. Earth-Science Reviews 186, 262-286.

Zhou, X.M., Li, W.X., 2000. Origin of Late Mesozoic igneous rocks in Southeastern China: implications for lithosphere subduction and underplating of mafic magmas. Tectonophysics 326, 269-287.

Zhou, X.M., Sun, Tao., Shen, W.Z., Shu, L.S., Niu, Y.L., 2006. Petrogenesis of Mesozoic granitoids and volcanic rocks in South China: A response to tectonic evolution. Episodes 
$29,26-33$.

Zhu, K.Y., Li, Z.X., Xu, X.S., Wilde, S. A., 2013. Late Triassic melting of a thickened crust in southeastern China: Evidence for flat-slab subduction of the Paleo-Pacific plate. Journal of Asian Earth Sciences 74, 265-279.

Zhu, K.Y., Li, Z.X., Xu, X.S., Wilde, S.A., Chen, H.L., 2016. Early Mesozoic ferroan (A-type) and magnesian granitoids in eastern South China: Tracing the influence of flat-slab subduction at the western Pacific margin. Lithos 240-243: 371-381.

Ziv, A., Rubin, A.M., Agnon, A., 2000. Stability of dike intrusion along preexisting fractures. Journal of Geophysical Research Solid Earth 105, 5947-5961.

\section{Figure captions}

Figure 1. (a) Sketch map of cratonic blocks and surrounding orogenic belts in China. NCC: North China Craton, SCB: South China Block, TC: Tarim Craton. (b) Tectonic framework and distribution of Mesozoic magmatism in the South China Block (modified from Faure et al., 2016 and Li et al., 2017).

Figure 2. (a) Geological map of the Shibei pluton and its surrounding areas with AMS sampling sites and occurrences of country rocks (simplified after BGMRFP, 1985). The foliations of the Mayuan Group and the bedding of the Late Jurassic sediments are plotted as great circles in the lower hemisphere and their poles are summarized with brown and blue contours in the lower hemisphere (Schmidt-Lambert projection), respectively. (b) Inferred cross-sections through the Shibei pluton and its country rocks according to the geological map and our field observations, AA' section in the NE-SW direction and BB' section in the NW-SE direction.

Figure 3. (a) Biotite-granite without macroscopic mineral-preferred orientation; (b) Sub-horizontal schlieren in granite near the north margin of the Shibei pluton; (c) Fine-grained biotite granite exposure in the south part of the Shibei pluton; (d) Migmatite country rocks with typical intrafolial 
fold; (e) and (f) Quartz-schist and phyllite with vertical foliation and crenulation of the phyllitic foliation can be observed; (g) Vertical contact surface between the Shibei pluton and Early Paleozoic migmatite observed at the eastern margin of the pluton.

Figure 4. Thin section images of the granite and sample locations noted in the Shibei pluton. Abbreviations of for minerals in the images are Amp: amphibole; Bt: biotite; Kfs: K-feldspar; Mag: magnetite; Per: perthite, Pl: plagioclase, Qtz: quartz, Ser: Sericite; Spn: sphene.

Figure 5. Magnetic mineralogical analyses of samples from the Shibei pluton.

Figure 6. Magnetic parameters of the granitic specimen from the Shibei pluton.

Figure 7. (a) Schmidt-Lambert projection of the AMS results from the individual sites in the Shibei pluton where gray and white equal-area projections present results of the northern and southern-central fabric groups, respectively. (b) and (c) Compiled projections of $K_{3}$ and $K_{1}$ components of the northern and southern-central groups, respectively.

Figure 8. (a) crystallization pressure vs. normative Qtz content (a) and (Ab + Or) content (b) of granite from the Shibei pluton (major elements data are compiled Wang et al., 2016).

Figure 9. (a) The residual Bouguer gravity anomaly map of the Shibei pluton and its surrounding areas. (b) Interpreted profiles of the Bouguer gravity anomaly of the Shibei pluton and its surrounding areas.

Figure 10. (a) and (c) Summary of the measured magnetic foliations and lineations, respectively. (b) and (d) Equal-area projections (lower hemisphere) of magnetic lineation and foliation poles as well as their corresponding density in specimen unit. The bold gray and thin black magnetic foliation and magnetic lineation symbols represent the vertical to sub-vertical and gently inclined magnetic foliations and magnetic lineations, respectively.

Figure 11. Proposed 3D cartoon model for the emplacement of the Shibei pluton with interpreted profiles (not in scale) along the black solid lines shown on the exposed cross section of the Shibei pluton. (a) initial dyke emplacement along the NE-SW trending feeder zone, (b) NE-trending dyke accretion to the north, and (c) overview of the relative consistency between fold/fault structure in the country rocks and magnetic foliation in the Shibei pluton. 
Hongsheng Liu: Investigation, Conceptualization, Software, Writing-Original Draft, Editing.

Yan Chen: Supervision, Conceptualization, Investigation, Review and Editing. Bo Wang:

Supervision, Conceptualization, Funding acquisition, Review and Editing. Michel Faure:

Supervision, Investigation, Review and Editing. Saskia Erdmann: Investigation, Review and

Editing. Guillaume Martelet: Methodology, Review and Editing. Bruno Scaillet:

Investigation, Review and Editing. Fangfang Huang: Investigation. 
Table 1. Sample information and site-mean AMS measurement results for granites of the Shibei pluton.

\begin{tabular}{|c|c|c|c|c|c|c|c|c|c|c|c|c|}
\hline \multirow{3}{*}{ Site } & \multirow{2}{*}{\multicolumn{2}{|c|}{ GPS coordinates }} & \multirow{3}{*}{$\begin{array}{l}\text { Alt. } \\
(\boldsymbol{m})\end{array}$} & \multirow{3}{*}{$n$} & \multirow{3}{*}{ Lithology } & \multirow{3}{*}{$\begin{array}{c}K m \\
\left(10^{-5} S I\right)\end{array}$} & \multirow{3}{*}{$\boldsymbol{P}_{J}$} & \multirow{3}{*}{$T$} & \multicolumn{4}{|c|}{ Site mean AMS results } \\
\hline & & & & & & & & & \multirow{2}{*}{$\begin{array}{c}K_{I} \\
D e c / I n c \\
\left(^{\circ}\right)\end{array}$} & \multirow{2}{*}{$\begin{array}{c}\alpha_{95} \\
(\max / \min ) \\
\left(^{\circ}\right)\end{array}$} & \multirow{2}{*}{$\begin{array}{c}K_{3} \\
D e c / I n c \\
\left(^{\circ}\right)\end{array}$} & \multirow{2}{*}{$\begin{array}{ll}\alpha_{95} & (\max / \min ) \\
& \left({ }^{\circ}\right)\end{array}$} \\
\hline & $\begin{array}{l}\text { Lat. } \\
\left({ }^{\circ} N\right)\end{array}$ & $\begin{array}{l}\text { Lon. } \\
\left({ }^{\circ} \boldsymbol{E}\right)\end{array}$ & & & & & & & & & & \\
\hline S01 & 118.440 & 27.847 & 213 & 8 & FBG & 1640 & 1.114 & 0.34 & $107.1 / 82.3$ & $35.9 / 10.8$ & $336.3 / 5$ & $13 / 3.6$ \\
\hline S02 & 118.429 & 27.856 & 237 & 5 & BG & 359 & 1.092 & 0.21 & $33 / 51.8$ & $22.1 / 6$ & $300.5 / 1.9$ & $25.9 / 15.9$ \\
\hline S03 & 118.357 & 27.926 & 273 & 8 & PG & 2400 & 1.087 & 0.40 & $330.5 / 32.5$ & $52.6 / 5.5$ & $132.7 / 56.2$ & $13.3 / 7.4$ \\
\hline S04 & 118.352 & 27.942 & 290 & 5 & PG & 1890 & 1.092 & 0.19 & $40.4 / 3.8$ & $19.2 / 3.6$ & $132.9 / 33.9$ & $13.5 / 3.3$ \\
\hline S05 & 118.379 & 27.555 & 152 & 6 & BG & 27 & 1.032 & 0.58 & $201.8 / 25.4$ & $12 / 1.5$ & $294.3 / 5.3$ & $18.8 / 6.6$ \\
\hline S06 & 118.359 & 27.557 & 213 & 6 & BG & 470 & 1.158 & 0.48 & $211 / 41.7$ & $17.1 / 10.8$ & $101.5 / 20.5$ & $15.7 / 5.8$ \\
\hline S07 & 118.343 & 27.563 & 276 & 7 & $\mathrm{FM}$ & 2 & 1.085 & 0.26 & $57.1 / 48.6$ & $20.4 / 12.5$ & $305.8 / 17.7$ & $24.8 / 6.2$ \\
\hline S08 & 118.338 & 27.561 & 383 & 7 & BG & 118 & 1.172 & 0.35 & $243.2 / 26.4$ & $20 / 6.5$ & $134.2 / 33.2$ & $8.2 / 5$ \\
\hline S09 & 118.324 & 27.564 & 485 & 5 & BG & 224 & 1.124 & 0.00 & $244.5 / 51.6$ & 26.8/0.9 & $136.1 / 14.1$ & $8.4 / 1.4$ \\
\hline S10* & 118.306 & 27.573 & 606 & 5 & FBG & 85 & 1.056 & -0.11 & $199.4 / 64.8$ & $20.4 / 9.9$ & $330.1 / 17.1$ & $34.1 / 7.2$ \\
\hline S11 & 118.350 & 27.547 & 277 & 5 & BG & 386 & 1.135 & 0.35 & $231.5 / 63.4$ & $16.9 / 8$ & $122.8 / 9.1$ & $9.1 / 7.4$ \\
\hline $\mathrm{S} 12^{*}$ & 118.326 & 27.540 & 660 & 6 & BG & 120 & 1.095 & -0.04 & $258 / 54.1$ & $30 / 17.3$ & $140.7 / 18.4$ & $21.8 / 5.7$ \\
\hline $\mathrm{S} 13$ & 118.343 & 27.535 & 440 & 5 & BG & 658 & 1.074 & 0.47 & $343.4 / 63.8$ & $40.5 / 6.1$ & $120 / 19.7$ & $12.6 / 9.7$ \\
\hline S14 & 118.333 & 27.595 & 379 & 5 & $\mathrm{BG}$ & 826 & 1.276 & 0.56 & $72 / 36.8$ & $5 / 4.2$ & $335.9 / 8.1$ & $4.5 / 2.9$ \\
\hline S15 & 118.338 & 27.584 & 139 & 8 & $\mathrm{BG}$ & 744 & 1.259 & 0.69 & $224.7 / 56.3$ & $30.7 / 2$ & $320.7 / 4$ & $3.5 / 2.1$ \\
\hline S16* & 118.353 & 27.575 & 113 & 6 & $\mathrm{BG}$ & 1150 & 1.081 & -0.60 & $208.9 / 22.3$ & $7.2 / 4.9$ & $105.2 / 29.8$ & $7.7 / 4.2$ \\
\hline S17 & 118.400 & 27.579 & 267 & 5 & BG & 423 & 1.072 & 0.18 & $232.9 / 19.8$ & $60.3 / 8.4$ & $127.9 / 35.7$ & $13.2 / 8.6$ \\
\hline S18 & 118.407 & 27.588 & 214 & 7 & $\mathrm{BG}$ & 79 & 1.061 & 0.22 & $66.3 / 20.8$ & $29.5 / 11.1$ & $326.5 / 24.1$ & $12 / 11$ \\
\hline S19 & 118.391 & 27.607 & 275 & 5 & BG & 41 & 1.071 & 0.08 & $185.8 / 56.7$ & $77.5 / 5.7$ & $338.1 / 30.2$ & $11.5 / 5$ \\
\hline
\end{tabular}




\begin{tabular}{|c|c|c|c|c|c|c|c|c|c|c|c|c|}
\hline $\mathrm{S} 20$ & 118.424 & 27.619 & 191 & 6 & $\mathrm{FM}$ & 21 & 1.034 & 0.20 & $203.5 / 51.7$ & $51.6 / 21.4$ & $113.3 / 0.2$ & $22.7 / 8.3$ \\
\hline S $21 *$ & 118.387 & 27.657 & 188 & 5 & $\mathrm{BG}$ & 2700 & 1.095 & -0.06 & $7.9 / 25.3$ & $17.5 / 4.6$ & $112.7 / 28.3$ & $24.3 / 5.4$ \\
\hline S22 & 118.389 & 27.664 & 183 & 9 & BG & 2740 & 1.098 & 0.37 & $315.9 / 69.9$ & $26.1 / 6$ & $58.4 / 4.5$ & $14.5 / 7.4$ \\
\hline $\mathrm{S} 23$ & 118.322 & 27.715 & 334 & 6 & FBG & 49 & 1.029 & 0.24 & $176.9 / 10.5$ & $43.5 / 13$ & $268.1 / 6.5$ & $13.9 / 5.3$ \\
\hline S24 & 118.331 & 27.720 & 281 & 5 & $\mathrm{FM}$ & 40 & 1.057 & 0.24 & $226.1 / 17.1$ & $46.6 / 5.2$ & $131.4 / 14.7$ & $12.5 / 4.9$ \\
\hline S25 & 118.369 & 27.709 & 223 & 5 & BG & 1840 & 1.138 & 0.08 & 208.2/49.2 & $62.6 / 32.5$ & $117.3 / 0.8$ & $34.2 / 31.9$ \\
\hline S26 & 118.390 & 27.779 & 373 & 11 & $\mathrm{BG}$ & 2130 & 1.181 & 0.45 & $33.8 / 46.8$ & $19.4 / 6$ & $138.2 / 13.2$ & $6.1 / 6$ \\
\hline S27 & 118.438 & 27.699 & 364 & 9 & $\mathrm{BG}$ & 511 & 1.074 & 0.34 & $202.4 / 66.5$ & $63.4 / 7.4$ & $294.7 / 1$ & $7.8 / 5.1$ \\
\hline S28 & 118.443 & 27.692 & 385 & 6 & BG & 180 & 1.049 & 0.27 & $224.7 / 6.4$ & $42.9 / 6.3$ & $134.5 / 1.7$ & $9.4 / 6.1$ \\
\hline S29 & 118.407 & 27.701 & 277 & 7 & $\mathrm{BG}$ & 2140 & 1.258 & 0.53 & $349.7 / 15.6$ & $8 / 4.7$ & $91.1 / 35.4$ & $6 / 1.7$ \\
\hline $\mathrm{S} 30$ & 118.407 & 27.738 & 234 & 5 & BG & 1110 & 1.105 & 0.33 & $149.4 / 4.8$ & $25.1 / 12.5$ & $241.1 / 19$ & $26.3 / 3.3$ \\
\hline S31 & 118.401 & 27.789 & 291 & 7 & BG & 1410 & 1.123 & 0.25 & $15.9 / 63.1$ & $13.2 / 3.8$ & $143.6 / 17.3$ & $8.2 / 3.8$ \\
\hline S32 & 118.431 & 27.714 & 450 & 8 & $\mathrm{BG}$ & 1590 & 1.241 & 0.21 & $287.5 / 67.7$ & $7.7 / 2.5$ & $123.7 / 21.5$ & $9.9 / 3.5$ \\
\hline S33 & 118.406 & 27.830 & 288 & 5 & FM & 483 & 1.077 & 0.25 & $303.7 / 37.8$ & $20.2 / 2.4$ & $176.3 / 38.1$ & $20.6 / 4.3$ \\
\hline S34 & 118.388 & 27.835 & 301 & 5 & BG & 30 & 1.05 & 0.37 & $43.2 / 20.9$ & $33.6 / 7.4$ & $160.6 / 50.3$ & $17.6 / 5.2$ \\
\hline S35 & 118.353 & 27.828 & 288 & 6 & BG & 47 & 1.05 & 0.04 & $358.7 / 36.8$ & $45 / 19.7$ & $110.7 / 26.6$ & $30.6 / 13.2$ \\
\hline S36* & 118.350 & 27.826 & 290 & 6 & FM & 8 & 1.014 & -0.03 & $33.2 / 25.8$ & $33.8 / 11.9$ & $222.5 / 63.9$ & $19.5 / 10$ \\
\hline S37 & 118.371 & 27.833 & 304 & 6 & FM & 41 & 1.033 & 0.05 & $97.1 / 5.8$ & $28.4 / 17.9$ & $191.1 / 34.5$ & $38.8 / 8.4$ \\
\hline
\end{tabular}

(1) The dark grey filled lines represent the data collected from the northern part of the Shibei pluton. * The asterisk indicates site with negative site-mean T value.

(2) Site: sampling site, Lat.: Latitude, Lon.: Longitude, Alt.: Altitude, n: number of specimens of each sampling site;

(3) Lithology: BG: biotite granite, PG: porphyritic granite, FM: fine grained monzogranite, FBG: fine grained biotite granite;

(4) $\mathrm{Km}$ : bulk magnetic susceptibility, $\mathrm{P}_{\mathrm{J}}$ : corrected degree of susceptibility anisotropy, $\mathrm{T}$ : shape parameter of the AMS ellipsoid, $\mathrm{K}_{1}$ : magnetic lineation, $\mathrm{K}_{3}$ : pole of magnetic foliation, Inc.: Inclination, Dec.: Declination, $\alpha 95(\mathrm{max} / \mathrm{min})$ : the long and short axes of the confidence ellipsoid at $95 \%$ level.

(5) Formulae to calculate the AMS parameters: $K m=\left(K_{1}+K_{2}+K_{3}\right) / 3, P=\exp \left\{\operatorname{sqr}\left[2\left(\left(n_{1}-n\right)^{\wedge} 2+\left(n_{2}-n\right)^{\wedge} 2+\left(n_{3}-n\right)^{\wedge} 2\right)\right]\right\}, T=\left(2 n_{2}-n_{1}-n_{3}\right) /\left(n_{1}-n_{3}\right)$, the $n_{1}, n_{2}$ and $n_{3}$ are the natural logarithm of $K_{1}, K_{2}$ and $K_{3}$ susceptibilities, respectively. $n=\left(n_{1}+n_{2}+n_{3}\right)$ 


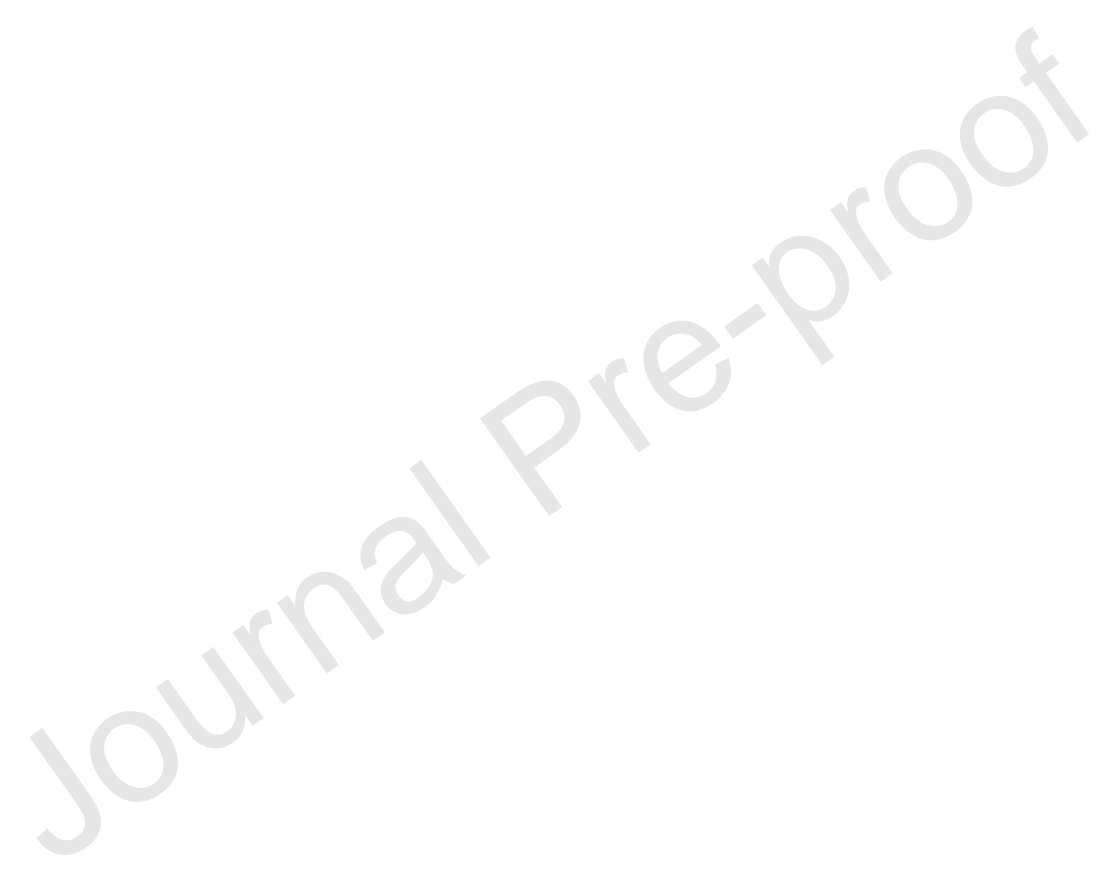




\section{Highlights:}

- Emplacement of the Late Jurassic Shibei pluton was assisted or guided by the inherited structures produced by pre-emplacement tectonic events.

- The pluton was constructed by a series of NE-SW striking magma injections commenced in the southern part of the pluton and laterally accreted to the northern part.

- The SE part of the South China Block is under a tectonic quiescence setting during late Jurassic epoch. 


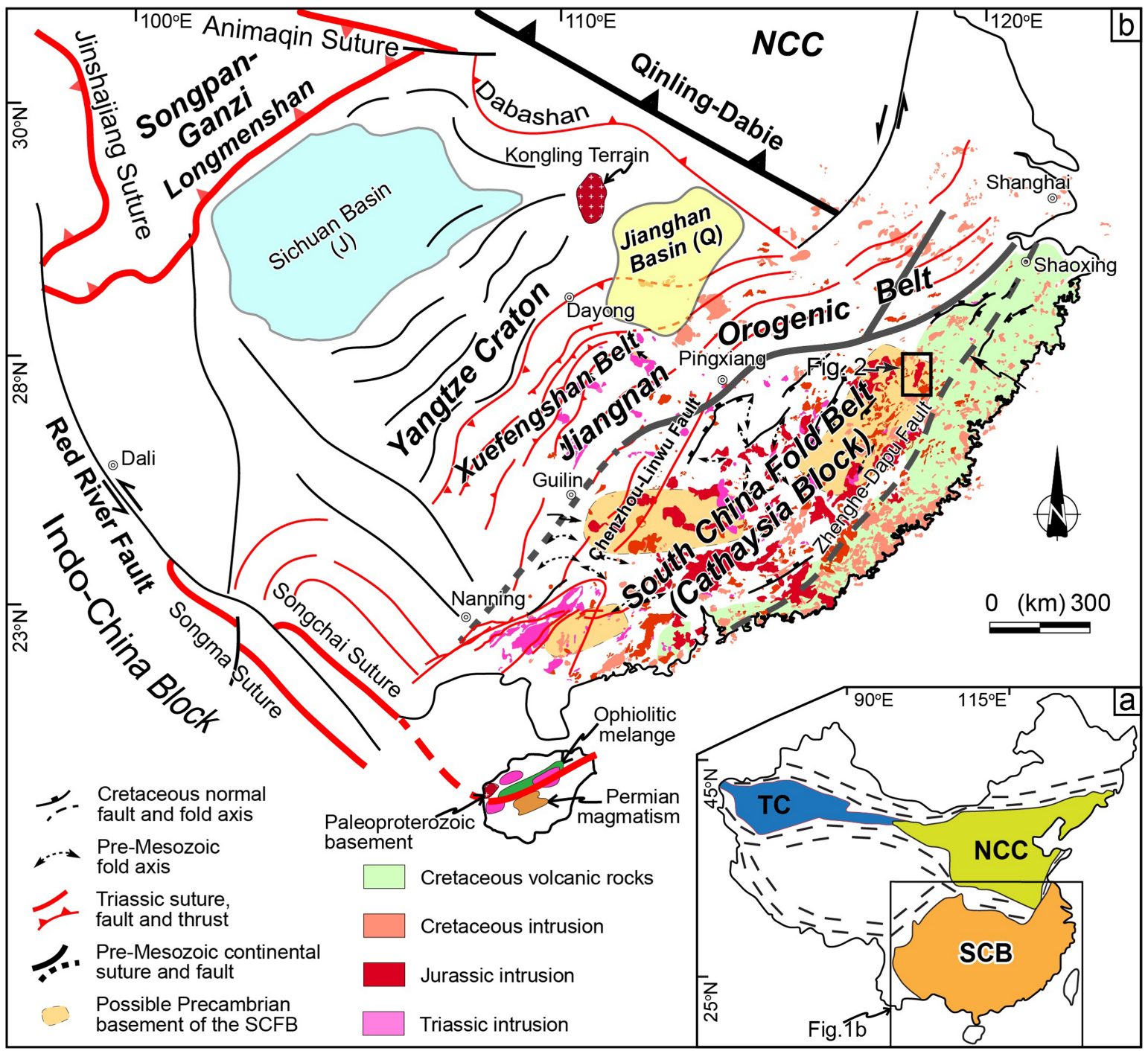

Figure 1 


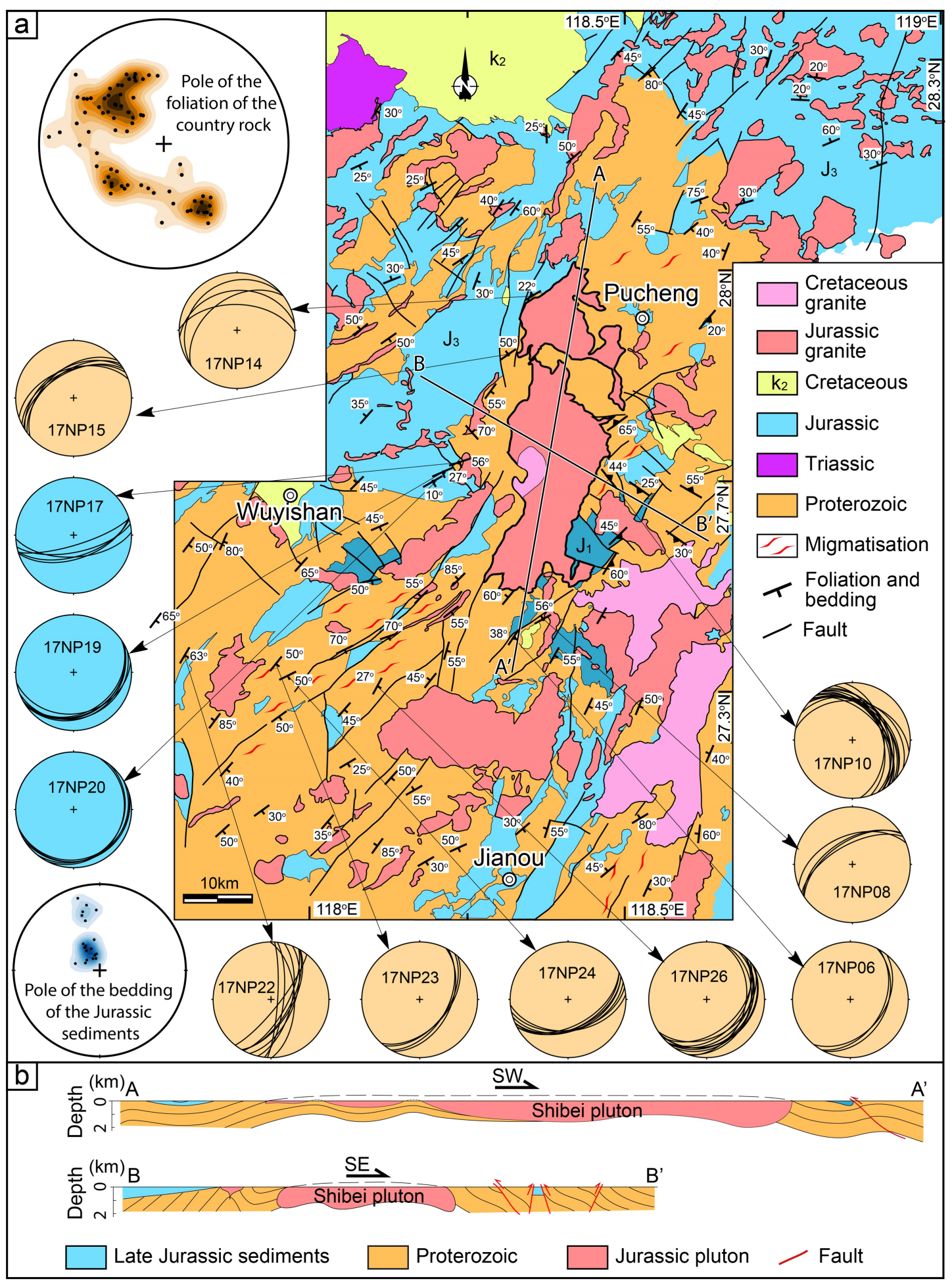



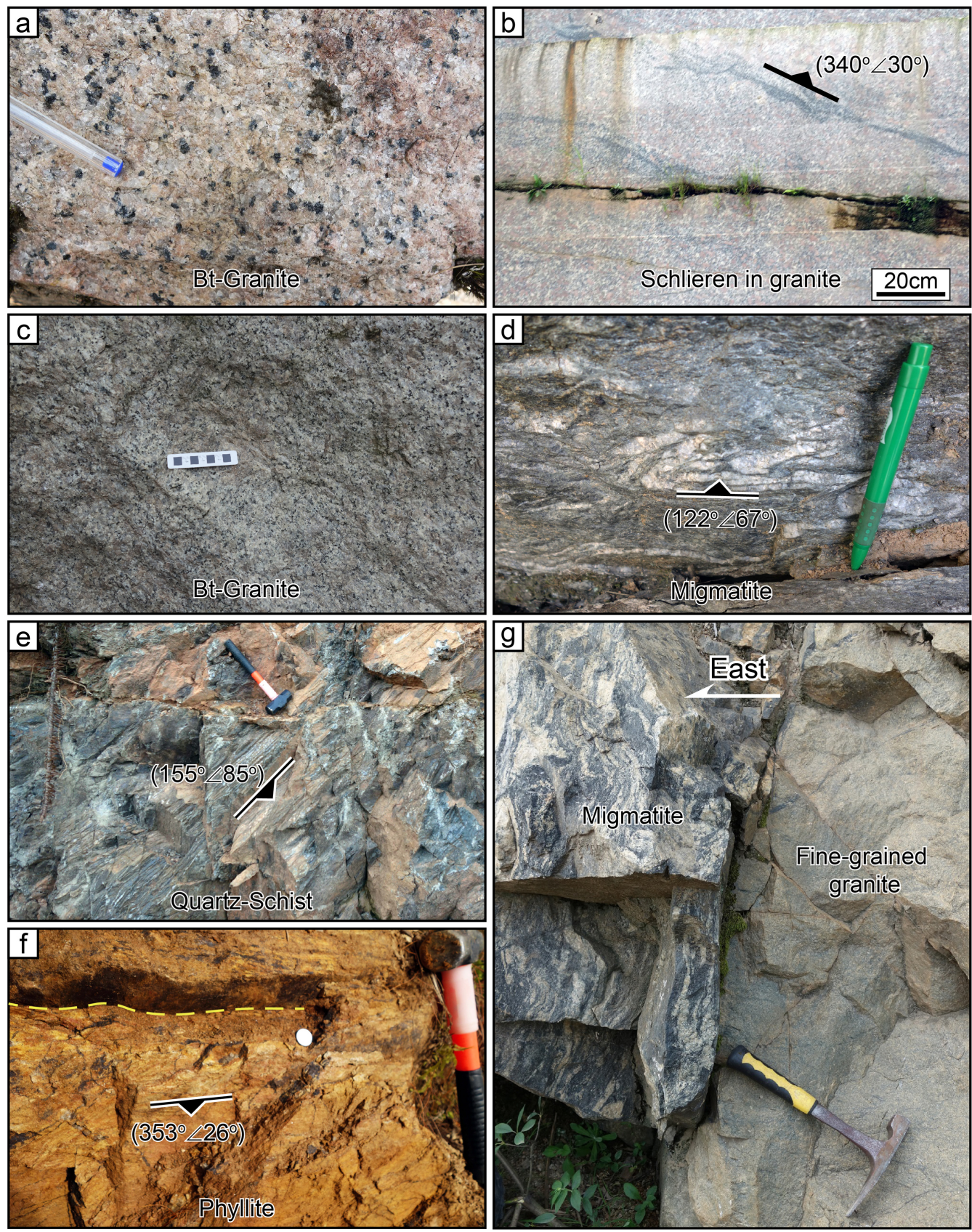

\section{East}

Migmatite

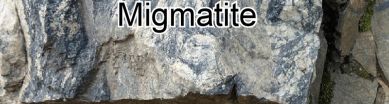

Fine-grained

granite

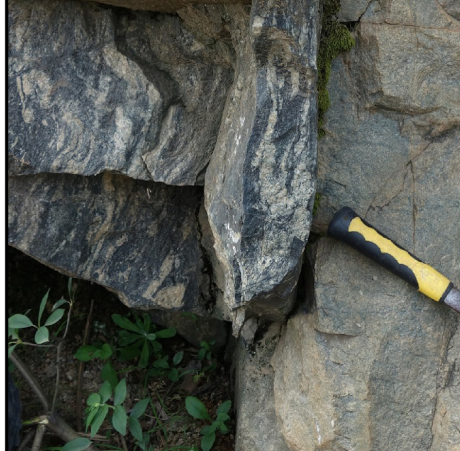

Figure 3 


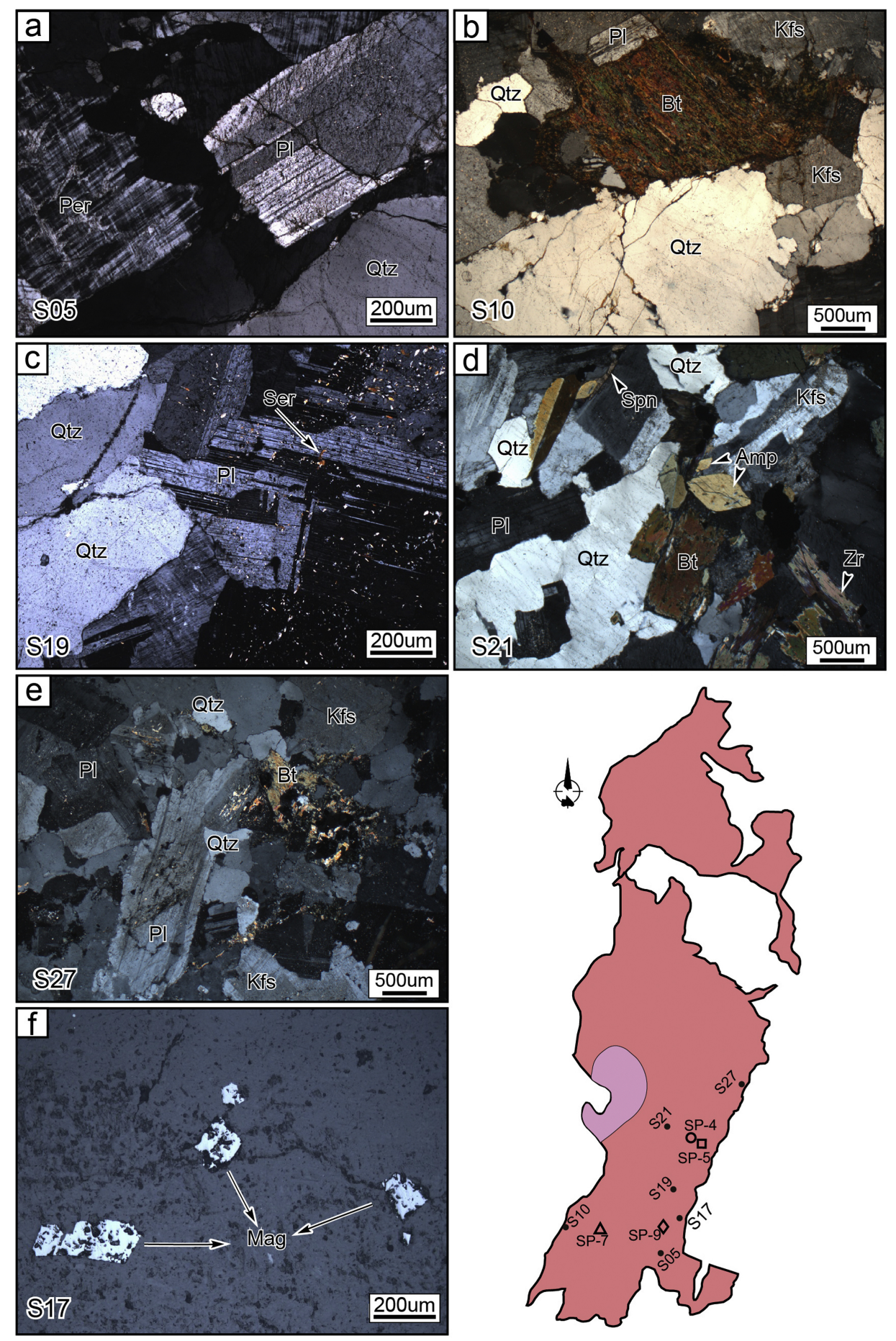



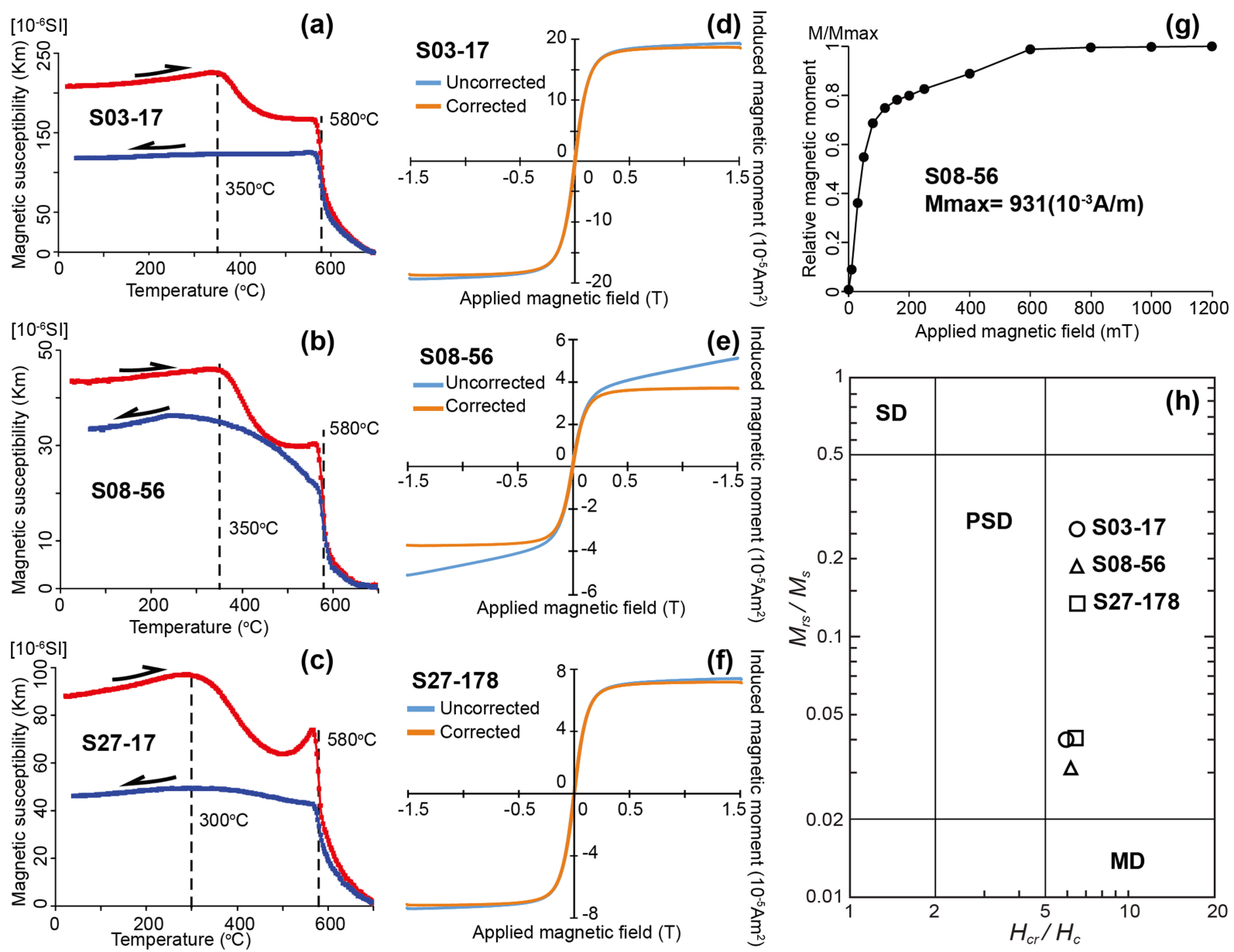

Figure 5 

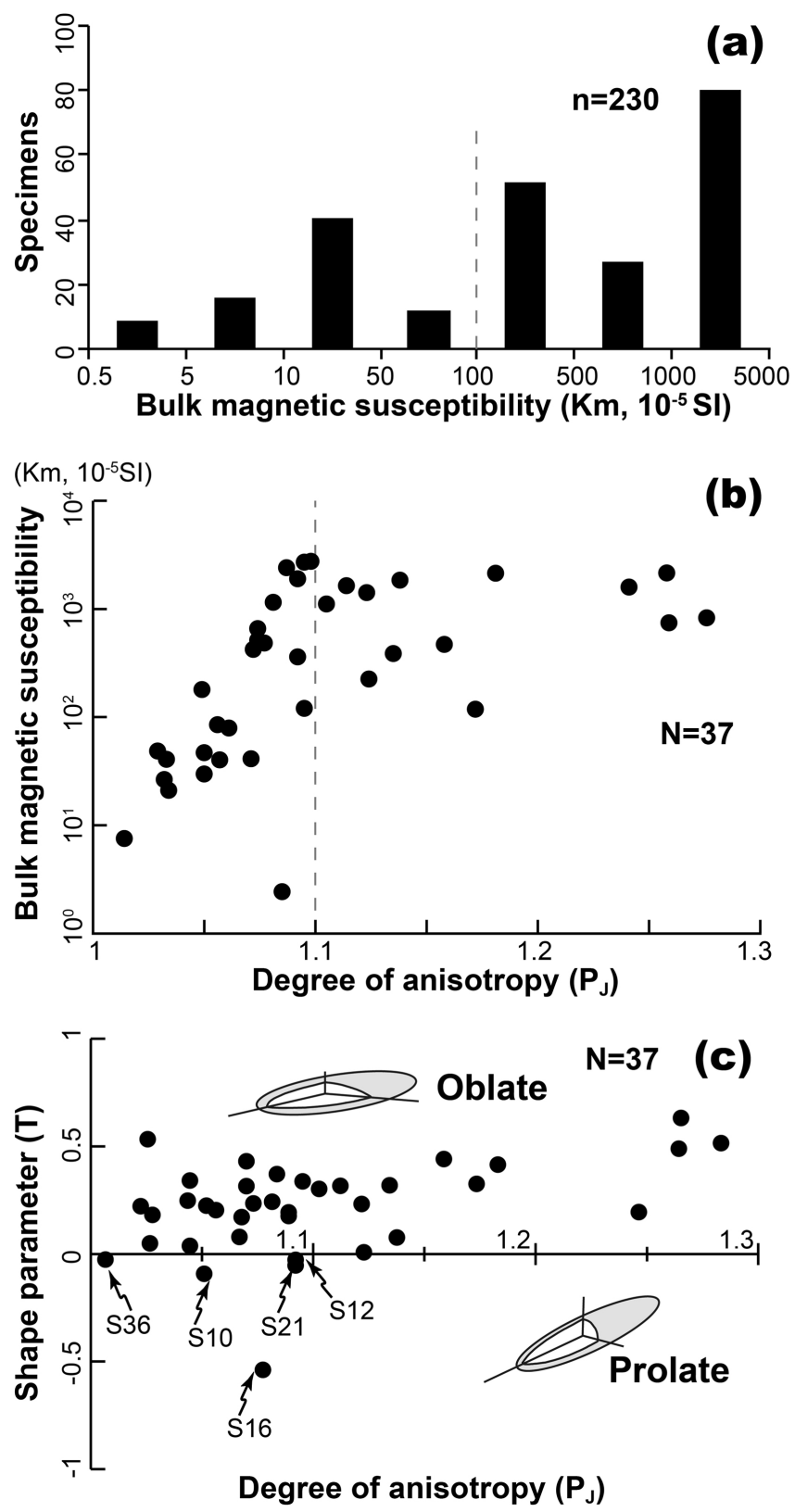


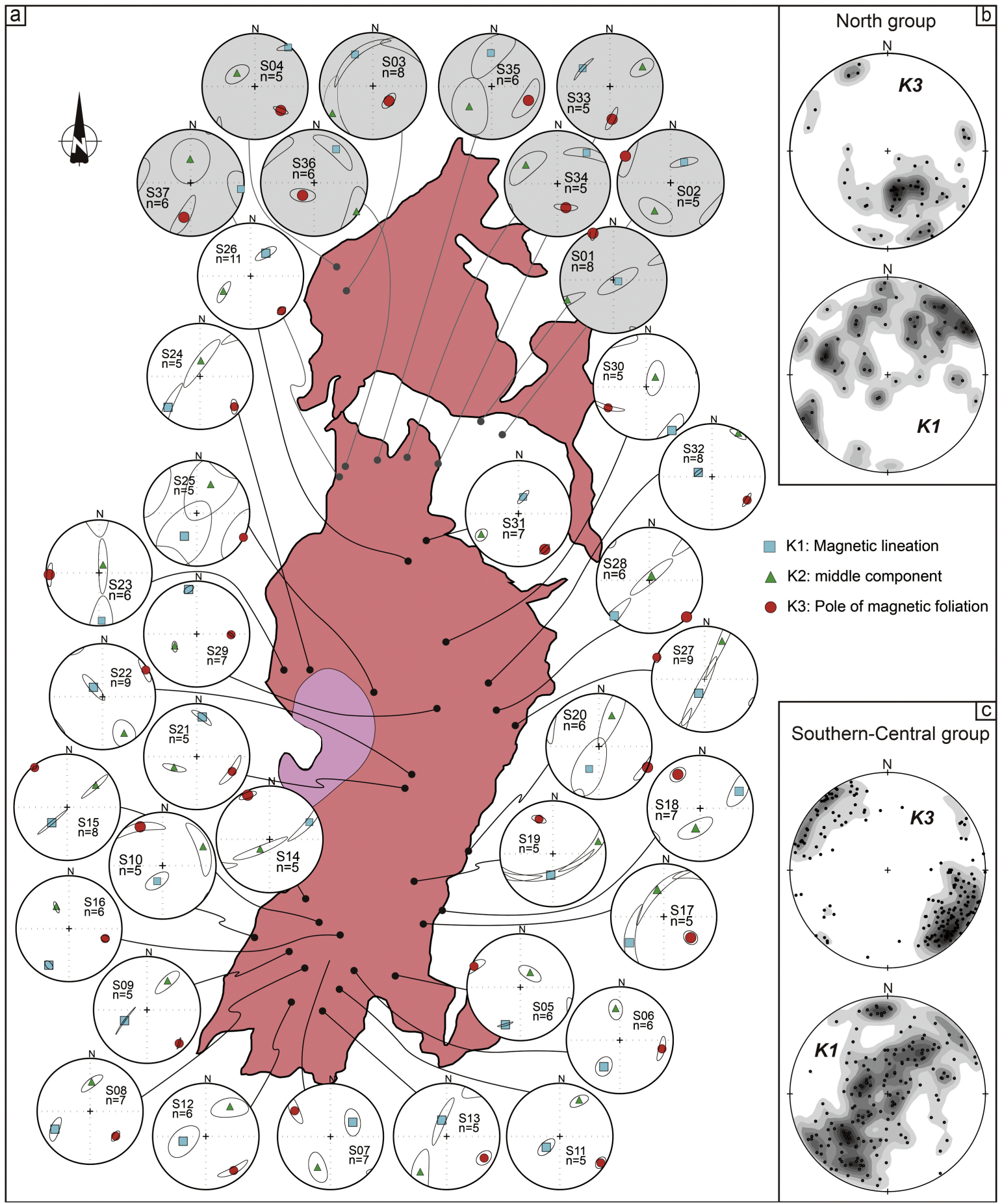

Figure 7 

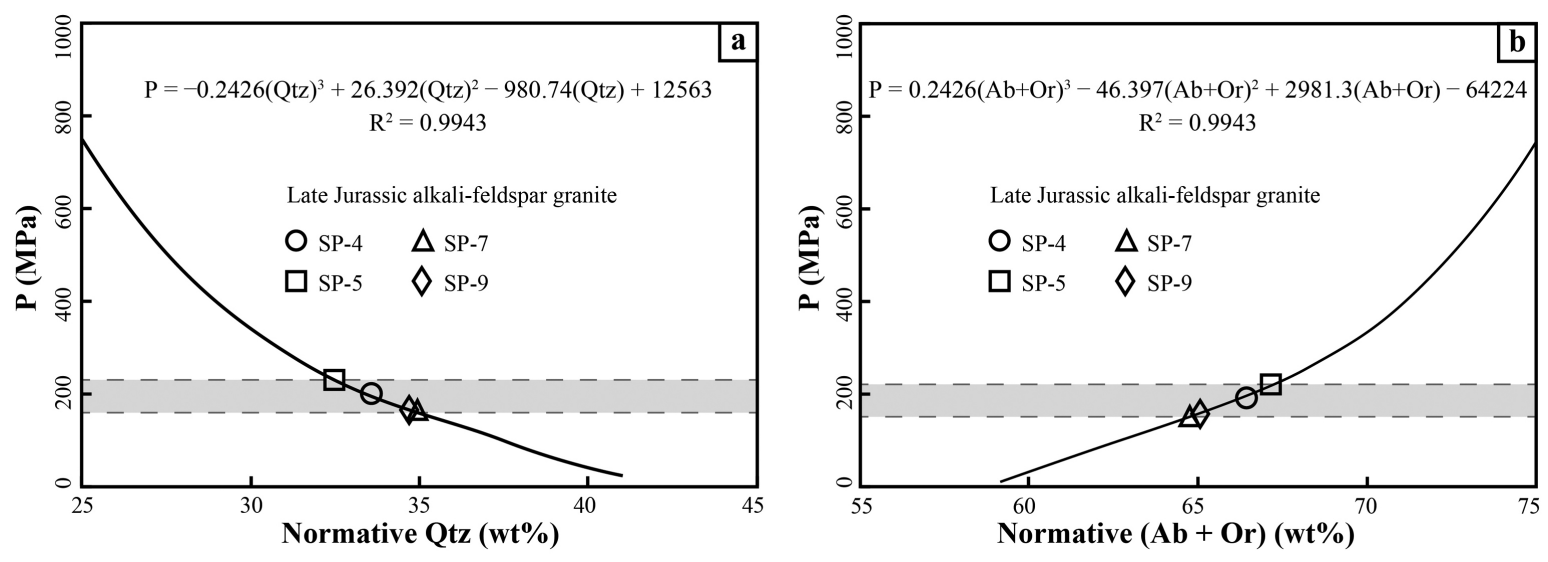

Figure 8 


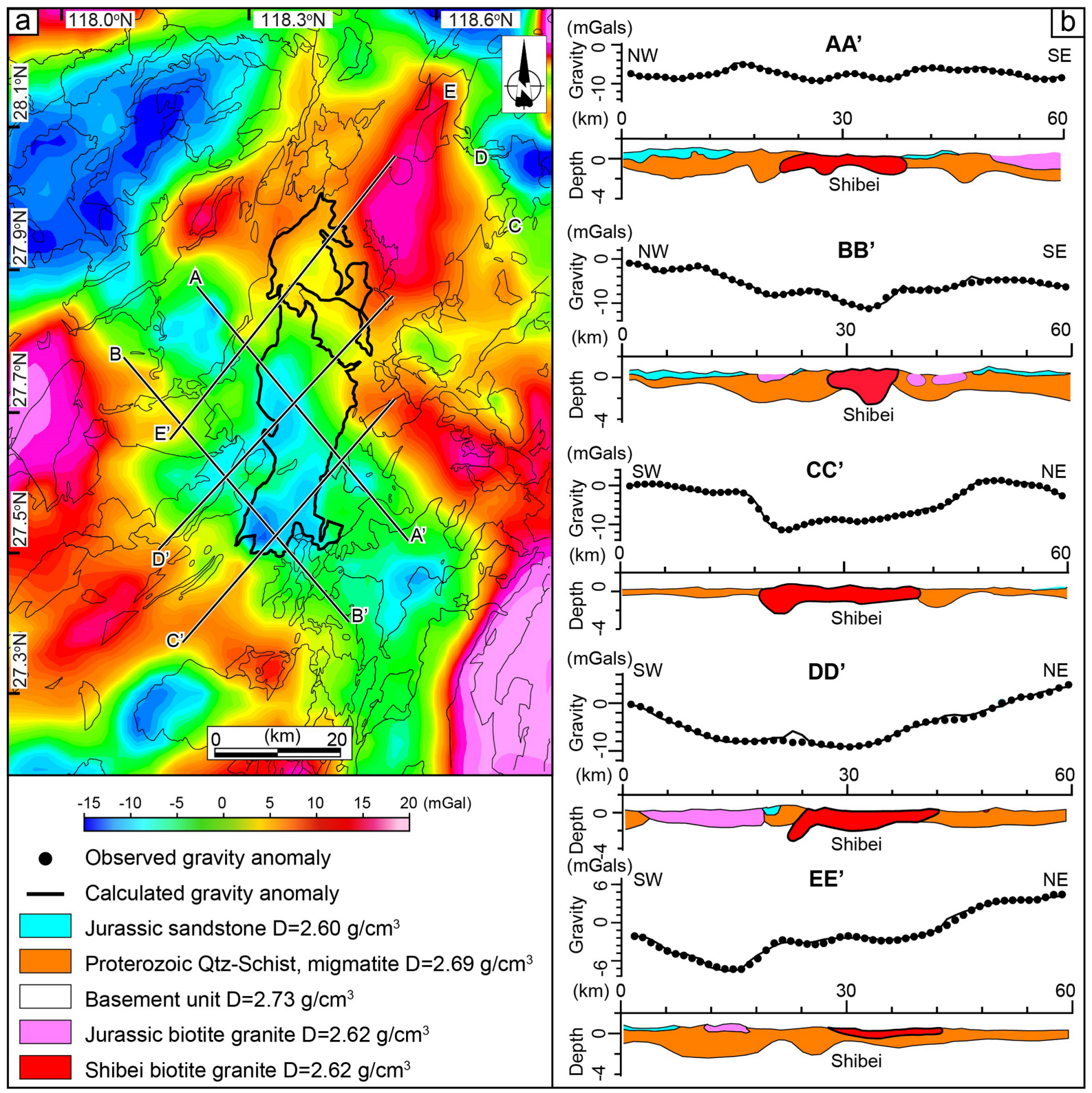

Figure 9 


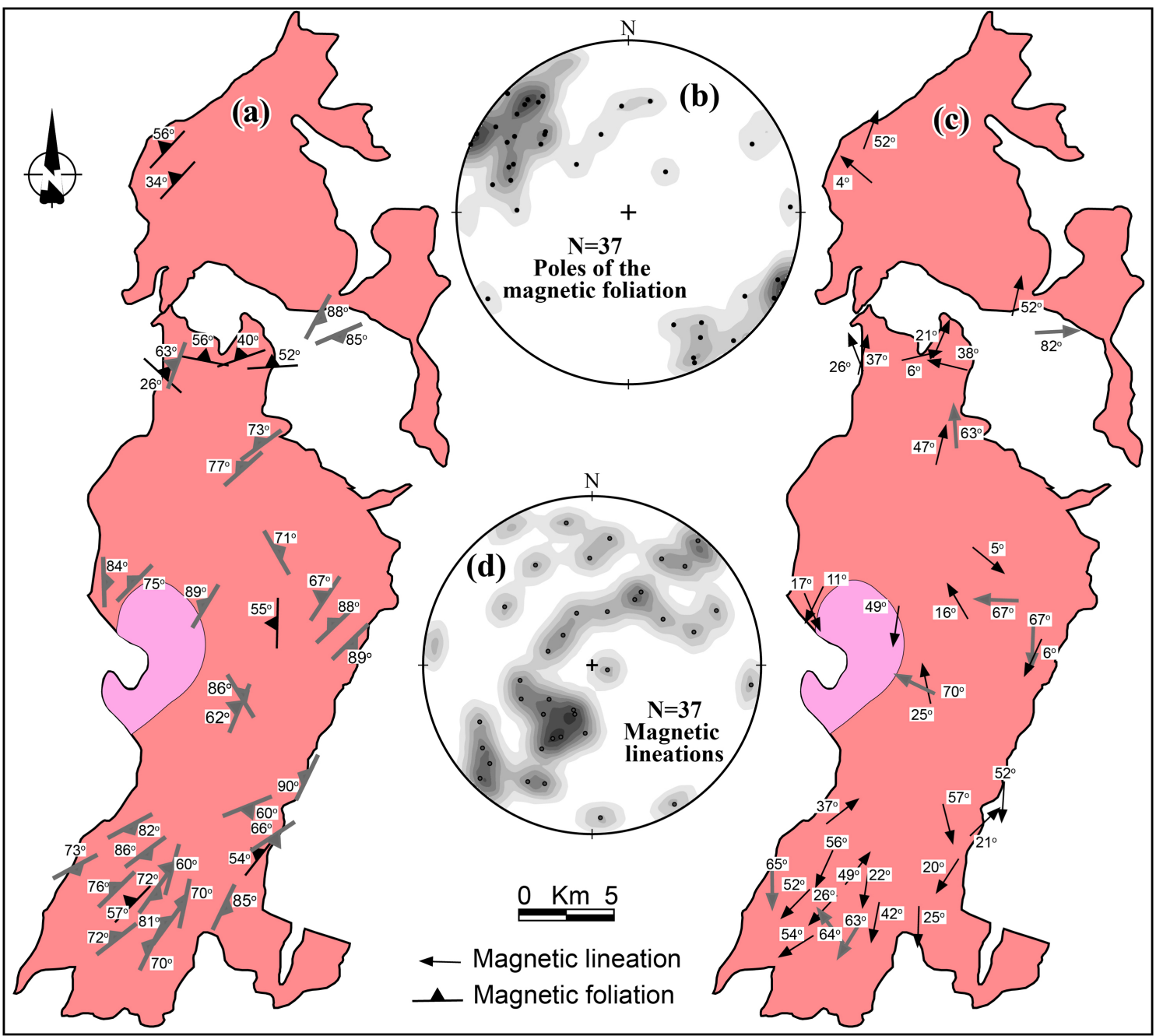

Figure 10 


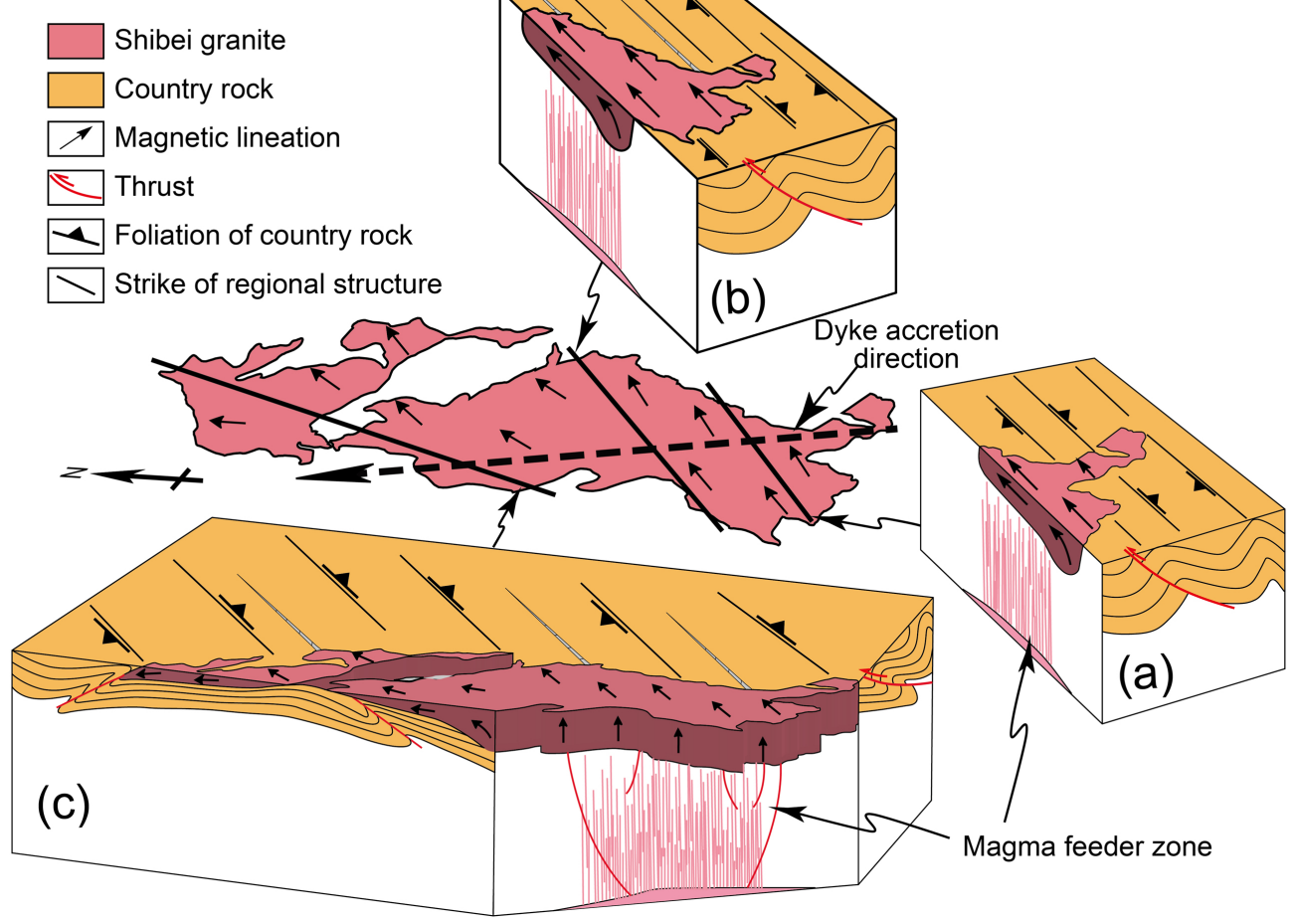

Figure 11 